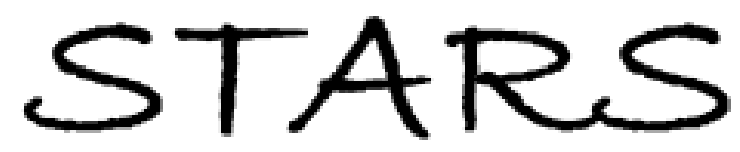

University of Central Florida

STARS

\title{
Whose Sustainability? An Analysis of a Community Farming Program's Food Justice and Environmental Sustainability Agenda
}

Sarah Davenport

University of Central Florida

Part of the Food Studies Commons, and the Social and Cultural Anthropology Commons

Find similar works at: https://stars.library.ucf.edu/honorstheses

University of Central Florida Libraries http://library.ucf.edu

This Open Access is brought to you for free and open access by the UCF Theses and Dissertations at STARS. It has been accepted for inclusion in Honors Undergraduate Theses by an authorized administrator of STARS. For more information, please contact STARS@ucf.edu.

\section{Recommended Citation}

Davenport, Sarah, "Whose Sustainability? An Analysis of a Community Farming Program's Food Justice and Environmental Sustainability Agenda" (2018). Honors Undergraduate Theses. 402.

https://stars.library.ucf.edu/honorstheses/402

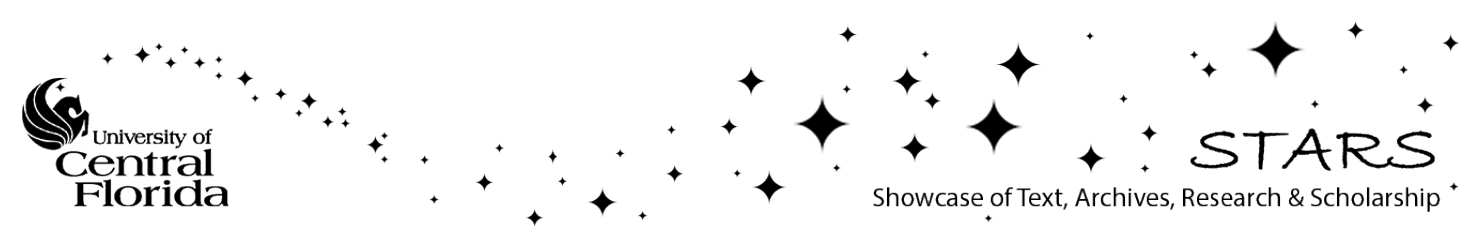




\section{WHOSE SUSTAINABILITY? AN ANALYSIS OF A COMMUNITY FARMING \\ PROGRAM'S FOOD JUSTICE \\ AND ENVIRONMENTAL SUSTAINABILITY AGENDA}

by

SARAH GRACE DAVENPORT

A thesis submitted in fulfillment of the requirements

for the Honors in the Major in the Department of Anthropology

in the College of Sciences

at the University of Central Florida

Orlando, Florida

Spring Term, 2018

Thesis Chair: Joanna Mishtal, Ph.D. 
(C)Sarah Grace Davenport 


\begin{abstract}
As the 1960s Environmental movement has grown, sustainability and justice discourses have come to the fore of the movement. While environmental justice discourse considers the unequal effects of environmental burdens, the language that frames "sustainability" is often socially and politically neutral. This thesis critically examines sustainability initiatives and practices of an urban farming organization in Florida. Based on ethnographic fieldwork in 2017, I explore the extent to which these initiatives incorporate race, ethnicity, and socioeconomic class when working to provide sustainably grown food in diverse communities. I argue that the organization's focus on justice for the environment, rather than for communities, and education as a barrier in low-income, food desert neighborhoods neglects to integrate experiences of those living on the margins into their initiatives. This research raises awareness of the need for a critical examination of sustainability in practice and a politically aware incorporation of environmental justice themes into sustainability agendas.
\end{abstract}

[Food and environmental sustainability, urban anthropology, environmental justice, social justice, political ecology, Florida] 


\section{ACKNOWLEDGEMENTS}

I would like to express my gratitude toward all the research participants from Fleet Farming who agreed to take part in this study. Thank you especially to Lee, whose drive and passion I greatly admire.

I would also like to thank my Honors in the Major Committee Members, Dr. Shana Harris and Dr. Neil Duncan for helping me build my methodological skills and refine the topic of this thesis. Thank you to my HIM Committee Chair, Dr. Joanna Mishtal for the support and the valuable feedback which has guided the direction of this project and helped me to develop critical analysis of urgent issues related to food insecurity. I would also like to thank my mentors and colleagues in the UCF Ronald E. McNair program for supporting me in my scholarly endeavors.

Finally, I would like to thank my family. Thank you to my brother, Brian, my best friend and number one advocate. Thank you to my parents, Kate Kingshott and Zar Davenport, who have taught me how to cultivate compassion for all people and instilled in me a passion to create more socially- and environmentally-just communities. 


\section{TABLE OF CONTENTS}

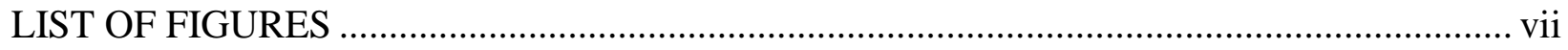

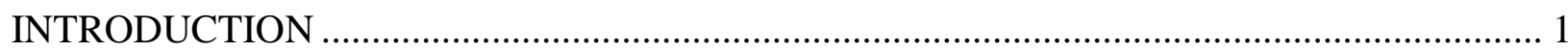

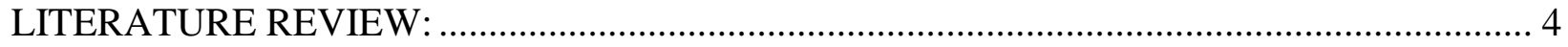

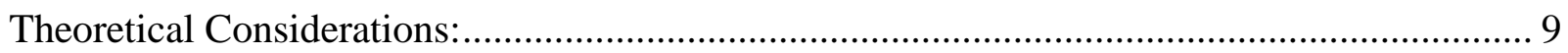

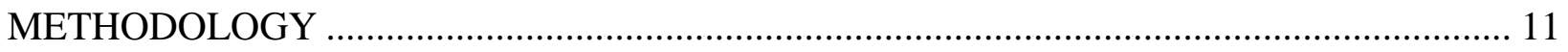

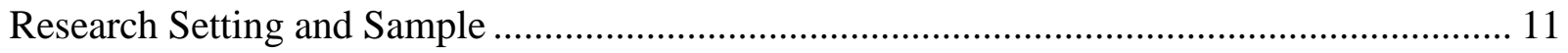

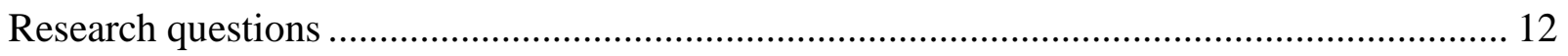

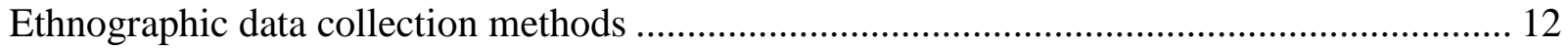

Participant Observation ............................................................................................... 12

Semi-structured and Informal Interviews ................................................................ 13

Historical, demographic and theoretical analysis ................................................... 15

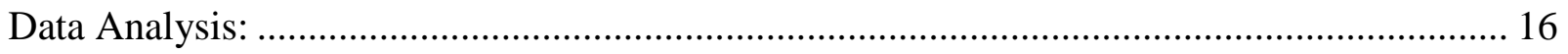

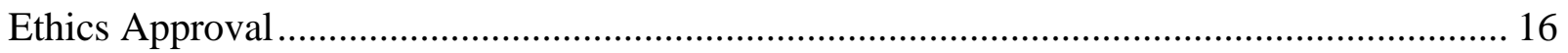

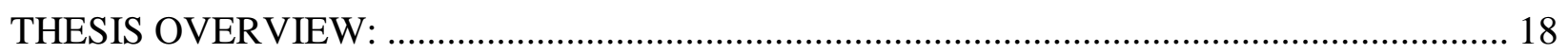

Chapter One: Environmental Justice as Justice for the Environment ................................... 20

"Trying to protect the planet": The Limits of Deep Ecology .......................................... 21

"You have to teach them to appreciate": Education as Solution? ..................................... 25

Chapter Two: Translating Good Intentions into Good Outcomes ..................................... 29

Colorblind but Class Conscious ................................................................................. 34

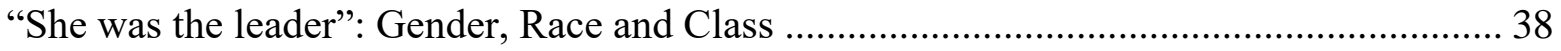


Chapter Three: Facing Political Realities through Engaged Anthropology .......................... 42

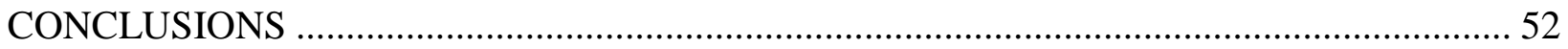

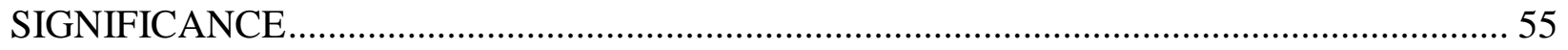

Engaged research with Fleet Farming ................................................................. 57

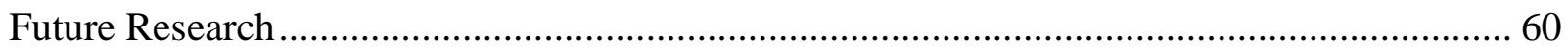

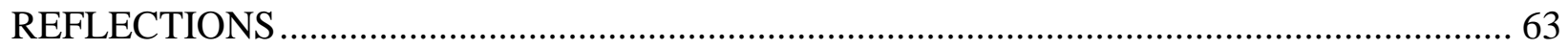

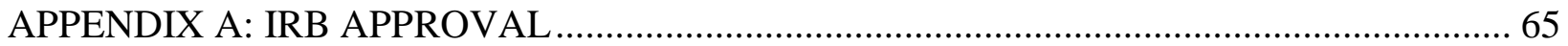

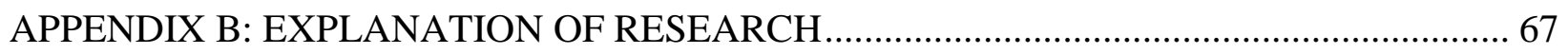

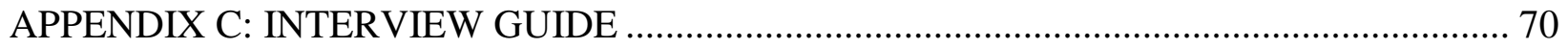

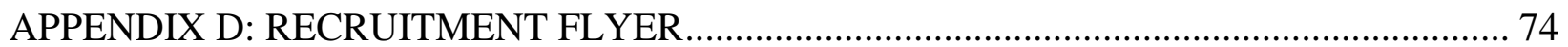

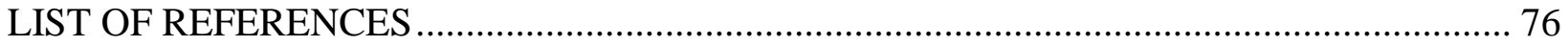




\section{LIST OF FIGURES}

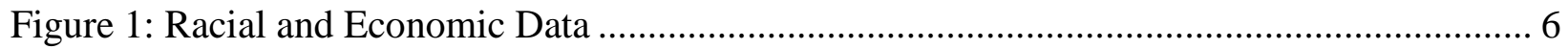

Figure 2: Audubon Park Swarm Ride........................................................................... 18

Figure 3: Elise farming at the Audubon Headquarters ...................................................... 23

Figure 4: Children at the Parramore Community Garden................................................... 27

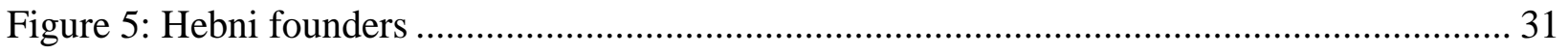

Figure 6: Caroline installing garden at Knowledge for Living ......................................... 35

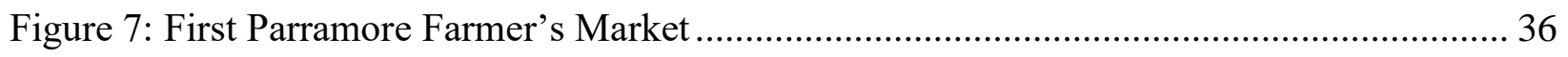

Figure 8: Lee and Caroline on a Swarm ride in Audubon Park .............................................. 38

Figure 9: Educational Garden in Audubon Park ............................................................... 40

Figure 10:Kaley Square Park and I-4 Construction ............................................................ 43

Figure 11: Map of Downtown and West Orlando ........................................................... 46

Figure 12: Lee installing garden at Knowledge for Living with Head Start program children .... 49 


\section{INTRODUCTION}

Environmental protection activism in the United States has been a discourse since the beginnings of the industrial revolution. Rachael Carson's Silent Spring (1962) and the first Earth Day in 1970 marked the beginning of an environmental movement in an urbanized nation, which focuses on quality-of-life issues (Gottlieb 1993, 7). As scientific research made environmental issues public, themes of race and class unintentionally arose to reveal that minorities were "disproportionately affected by unhealthy air, unsafe drinking water, dangerous chemicals, lead, pesticides, and toxic wastes" (Bullard 1994, 20). In 1982, the National Association for the Advancement of Colored People rallied people to protest the decision to locate a toxic waste facility in an African-American town in North Carolina. From this arose the environmental justice movement, which "became a national social and racial protest that galvanized communities across the country seeking social justice and environmental protection."1 Simultaneously, environmental sustainability has come to the fore of grassroots environmental movements to solve environmental justice issues. However, the language that defines and surrounds the usage of the term "sustainability" focuses on the interconnectedness of ecological and social problems, assuming the term and concept are politically and socially neutral. Such apolitical sustainability discourses overlook and sometimes perpetuate socioeconomic inequalities since the apolitical assumptions of sustainability ignore the historical, social and political contexts of communities (Checker 2011, Gunder 2006). Thus, there is need for scholars to pay

\footnotetext{
${ }^{1}$ For more information on the history of environmental justice see: "Environmental Justice History" https://energy.gov/lm/services/environmental-justice/environmental-justice-history, accessed January 15, 2018.
} 
critical attention to environmentally sustainable initiatives and their effects in marginalized communities. Although current scholarship engages in environmental justice issues, scholarly inquiries about the extent to which sustainability groups/programs incorporate social justice concepts into their environmentally sustainable initiatives remains understudied. Therefore, the effects of such actions in different communities are poorly understood and remain important for anthropologists and other scholars to research.

This study focuses on Fleet Farming, an urban farming organization in Orlando, Florida, and examines if and how this organization considers peoples' varied racial, ethnic, and socioeconomic backgrounds when constructing their agendas and implementing sustainability projects in marginalized communities. Fleet Farming was originally founded by a group of grassroots environmentalists in Audubon Park, an upper-middle economic class, predominantly white "eco-friendly" neighborhood in the bustling Downtown Orlando area. This year, they were preparing to expand their first branch to Parramore, a historically African-American, lowincome, food desert neighborhood. Through an investigation of their agenda and practices, I show how Fleet Farmers understand environmental justice in terms of their upcoming branch expansion. I demonstrate how their understandings unintentionally and subtly dissociate sustainability from "the political," or socio-political conflicts. I argue that, in light of the contrasting social contexts of Audubon Park and Parramore, environmental sustainability practices should be adapted to the specific socioeconomic context of each neighborhood. Such adaptation of practices would require organizations such as Fleet Farming to understand deeply rooted social inequalities and recognize how this might affect their work in communities such as Parramore. However, without this recognition, such initiatives can serve to perpetuate inequities 
they intend to address. This research suggests that, despite understanding that environmental problems have disproportionate effects on marginalized communities like Parramore, Fleet Farming assumes that their sustainable initiatives will positively impact all people equally, regardless of their circumstances. 


\section{LITERATURE REVIEW:}

\section{SUSTAINABILITY PROJECTS IN DIVERSE CONTEXTS}

Fleet Farming is an Orlando-based urban farming non-profit program parented by Intellectual Decisions on Environmental Awareness Solutions (IDEAS). IDEAS is an international, United-Nations-accredited charity organization, which finds sustainable, local, and socially just solutions to environmental problems. Local environmentalists created Fleet Farming at an IDEAS think/do tank meeting, the Hive, in the Audubon Park ecodistrict. At the monthly Hive meetings, environmentalists collaborate to "[address] global challenges through local solutions to advance [environmental] sustainability."2 In the spring of 2015, the Hive topic was "food sustainability" and the solution Audubon Park residents created was the Fleet Farming program and urban agricultural model. Today, Fleet Farming works in Audubon Park, an uppermiddle-class neighborhood located near the heart of Downtown Orlando, destroying grassy lawns and installing edible gardens at over 20 homes. Fleet Farming targets homeowners in Audubon Park who are willing to donate their yard, can pay the $\$ 50$ consultation and $\$ 500$ onetime installation fees and can ensure that they have not treated their lawns with any pesticides or fertilizers for at least two years. Fleet Farming employees, interns, and bi-weekly volunteers ride their bikes to tend to the garden plots at each home, known as "farmlettes." Ultimately, the goal of this program is to educate communities about the importance of hyper-local (i.e., within the

\footnotetext{
${ }^{2}$ For more information on IDEAS see: "About" https://ideasforus.org/about/, accessed January 10, 2018.
} 
neighborhood) farming and engage them in Fleet Farming's method of sustainability: to grow organic, hyper-local food instead of "water-greedy," pesticide-heavy lawns.

Fleet Farming's founding community, Audubon Park, is a recently developed residential neighborhood that was previously a military base. Since the 1990s, the area has grown into a sustainable food and business district, or "ecodistrict," known as Audubon Park Gardens. ${ }^{3}$ Parramore, the neighborhood in which Fleet was preparing to expand during the fall of 2017, is a historically African-American town on the opposite side of the segregating railroad tracks and interstate (I-4) from Audubon Park. In 1884, James B. Parramore founded the Parramore neighborhood as an African American town for black people who worked in the homes and citrus groves of white, Orlando residents. Today, Parramore remains divided from the wealthier downtown neighborhoods, including Audubon Park, by structures such as I-4. Current development projects, such as the Orlando City Stadium, are continuing to push people to the margins of the city. Historical segregation, gentrification, and oppression are the contexts I am considering as I analyze how Fleet Farming was preparing to expand into Parramore in the fall of 2017. In light of these contrasting social, economic (see Figure 1), and environmental contexts, Fleet Farming's first expansion raises concerns about how they plan to initiate sustainability equitably, and how they translate their methods from the affluent Audubon Park neighborhood to the low-income Parramore neighborhood.

\footnotetext{
${ }^{3}$ For more information about the Audubon Park Ecodistrict see: "About" https://audubonparkgardens.com/about-2/, accessed March 15, 2018.
} 
Figure 1: Racial and Economic Data

\begin{tabular}{|l|l|l|}
\cline { 2 - 3 } \multicolumn{1}{l|}{} & Parramore & Audubon Park \\
\hline Total Population & 22,111 & 16,669 \\
\hline Black/ African-American & 16,414 & 322 \\
\hline White & 2,596 & 13,466 \\
\hline Hispanic/Latino & 2,325 & 1882 \\
\hline Asian & 206 & 679 \\
\hline Multi-racial & 540 & 312 \\
\hline Median Income & $\$ 36,028$ & $\$ 76,611$ \\
\hline Poverty Rate & $36.9 \%$ & $10.20 \%$ \\
\hline
\end{tabular}

2015 American Community Survey

Dominant narratives of sustainable urban agriculture, in particular, are limited to the social benefits of urban farming and disregard its potential to reinforce structural inequalities (Reynolds 2015). Those narratives that address environmental injustice, but fit with other dominant narratives centered on the benefits of urban farming, might serve to obscure or reinforce structural inequalities (Reynolds 2015; Checker 2011; Clendenning 2016). Still, qualitative studies on sustainability projects, like urban agricultural programs, predominantly analyze them as a way to encourage local food production and distribution, provide green space in urban environments, and improve access to fresh foods (Mello et al. 2017; Larsen \& Gilliland 2009; Poulsen et al. 2014). While it may be true that such projects improve sustainability and access to fresh foods, social and economic challenges to equitable, urban food systems have 
prompted a rise in scholarly and activist engagement in social justice in the food system. This interest has resulted in increased importance for understanding the structural roots of food and environmental injustice, particularly concerning race-and class-based disparities (Clendenning et al. 2016; Reynolds 2015).

Previous scholarship reveals the need to analyze alternative agro-food organizations that express interest in and support social justice goals, since the incorporation of such goals into onthe-ground alternatives is often tenuous (Allen 2008, 159). Even though Fleet Farming does not explicitly claim to be an "environmental justice" program, their goals to bring food security into a marginalized community are inherently justice themed. Research on sustainable urban projects also reveals depoliticizing trends in US food and sustainability movements. As a result, these politically neutral conclusions make it difficult for actors to build substantial support and power for alternative food systems (Clendenning et al. 2016). This thesis therefore builds on the environmental justice scholarship by investigating the degree to which Fleet Farming's goals are socially just, and how Fleet incorporates these goals into their new initiative planning.

Scholars critical of the extent to which proclaimed sustainability solutions to food inaccessibility are available to low-income people, have found race to be a significant barrier as well (Lambert-Pennington \& Hicks 2016). Anthropologists Katherine Lambert-Pennington and Kathryn Hicks found notions of a "colorblind" form of justice that rejects the legitimacy of race as a frame of understanding access and participation in alternative food networks in general $(2016,58)$. A lack of recognition of racial inequalities might overlook the significance of how alternative food networks, such as farmer's markets or urban gardening programs, shape the meaning of community engagement, access, and belonging within alternative food movements 
(Lambert-Pennington \& Hicks 2016; Guthman 2008). Structural violence, or the social structures characterized by poverty and social inequalities (Farmer 2004), frames the issue in this study to provide a lens for understanding the importance of race and poverty in the context of Parramore.

Current scholarship also addresses the economic accessibility of food, especially in food deserts (like Parramore), which are areas where over $20 \%$ of people live at or below the federal poverty line, and at least 33\% of the population lives over a mile from a grocery store with fresh produce. ${ }^{4}$ Limited food landscapes in food deserts lack viable options for healthy, affordable food (Passidomo 2014, 389). Social science research has shown that introducing food resources like a farmers' market to a food desert, increases the availability of healthy food and decreases overall food costs (Larsen \& Gillilan 2009, 1160). However, geographer Catarina Passidomo (2014) found that even in cases where such organizations begin with goals to address issues of food justice, they may not be able to sustain these goals because of the necessities associated with meeting the priorities of funders and maintaining economic viability.

Given the rise in scholarly engagement with topics of food justice, primary areas of scholarship on food and environmental justice, anthropology and geography, have followed this shift to analyzing such issues within a critical framework. Anthropological research on urban food and environmental sustainability focuses on how social inequalities result in environmental injustices. Although anthropological scholarship links environmental injustice with structural inequalities, there is little critical analysis on how those inequalities shape the practice and effects of sustainable solutions to food and environmental injustices. However, qualitative

\footnotetext{
${ }^{4}$ For list of related definitions see: https://www.ers.usda.gov/data-products/food-access-researchatlas/documentation/, accessed March 3, 2018.
} 
research in human geography has begun to engage in issues related to social justice, or lackthere-of, within urban sustainability initiatives and practices. Human geography scholarship more critically examines how sustainable solutions to urban environmental inequalities-like implementing a sustainable urban agriculture program to solve inadequate access to fresh food, for example—emerge and operate in different contexts.

My research of Fleet Farming's transition to address food and environmental injustice in a marginalized community builds on this shift in scholarship. Specifically, this project examines if and how Fleet Farming, as a community program, considers the structural roots of this injustice, how the program's volunteers and interns understand the needs of people of different socioeconomic classes, races, and ethnicities when it comes to food security and sustainability, and how Fleet plans to address these challenges. I also consider the larger historical, economic, and political context of the relationship between food insecurity and complex societal and economic barriers experienced by marginalized communities.

\section{Theoretical Considerations:}

I theorize this thesis using two guiding frameworks of structural violence (Farmer 2004) and political ecology (Greenberg and Park 1994). James Greenberg and Thomas Park’s (1994) political ecology framework guides this study to analyze the relationships between the environment, politics, and society. This guiding framework allows me to contextualize the social, political, and environmental circumstances in Parramore and Audubon Park. Political ecology facilitates my analysis of food insecurity that goes beyond just highlighting Parramore's limited access to fresh foods; my political ecology theoretical approach helps me to show how food 
insecurity is tied to the environmental and individual health of the community, contemplate the political and economic factors of poverty, and investigate racial inequalities within sustainability rhetoric and practice. Approaching this issue using the lens of structural violence, that is, the political, social, and economic "web" of exploitation (Famer 2004, 317), helps me to understand how food insecurity in Parramore today is one piece of a larger history of racism and socioeconomic exclusion. I accompany a "historically deep" (Farmer 2005, 42) viewpoint with current demographic data and information about on-going initiatives/developments in Parramore to explain the factors of structural violence there. Previous research on this topic lays the foundation for my research on the relationships between sustainability,race and class. 


\section{METHODOLOGY}

\section{$\underline{\text { Research Setting and Sample: }}$}

I based this thesis on three months of ethnographic research carried out during May, June, and September in 2017 at the original Fleet Farming headquarters in the Audubon Park neighborhood of Orlando, FL. These headquarters included Fleet Farming's physical office, the East End Market community garden, ${ }^{5}$ and the different homes with farmlettes all throughout the Audubon Park area (see Figure 11). I draw on fieldwork conducted with 26 Fleet interns and the 3 employees at the Audubon Park branch. Most Fleet Farming interns hold internships that last for three to six months. This ethnographic research also builds on my two years of active participation in environmentalist groups and activities in Orlando, FL, between 2016 and 2018. One such group is Orlando Permaculture,${ }^{6}$ a group of Central Florida residents who follow the permaculture social and ecological design system that mimics environmental processes and relationships. Another is IDEAS for UCF, the original IDEAS club, founded by Chris Castro, the current president of IDEAS for US (the 501(c)(3) non-profit organization) and Orlando City Director of sustainability. Between 2016 and 2018, I have also frequented multiple farmer's markets in Orlando, volunteered in the UCF garden, and participated in social events related to ecology, agriculture, and sustainability. Yet, the Fleet Farming program is unique, its innovative methodology (i.e., educational lawn farming) makes it highly popular, which was overshadowing

\footnotetext{
5 See final paragraph "market garden": https:/www.eastendmkt.com/visit/our-neighborhood/
}

${ }^{6}$ For more information on Orlando Permaculture see: http://orlandopermaculture.org/ 
the fact that the program itself is enmeshed in a complex structure of power in Orlando. Given these intricate socio-political entanglements in which Fleet operates, valid questions emerged about Fleet's role in this structure and how the program operates in relation to the communities it aims to serve. Therefore, I selected Fleet Farming as a suitable research site in which to situate my project.

\section{$\underline{\text { Research questions }}$}

The three questions that guided this project are the following:

1. Who is represented within the sustainability movement in the Central Florida area?

2. Does Fleet Farming incorporate environmental justice in their agenda and, if so, how?

3. How does their agenda and practices consider people of different socioeconomic classes, races, and ethnicities?

\section{Ethnographic data collection methods}

To answer these questions, I used the following ethnographic data collection methods:

\section{Participant Observation:}

I carried out participant observation to take part in Fleet Farmer's regular activities. During the morning intern shift, we rode bicycles around Audubon Park to tend to each farmlette. Our 
farming activities included harvesting plants, removing weeds, turning the soil in each row and seeding plots. Intern shifts in the afternoon included processing produce at headquarters to sell at farmer's markets and to local businesses. I also participated in Swarm Rides (see Figure 2), ${ }^{7}$ which are free events, every second and fourth Sunday of the month, hosted in Audubon Park. During Swarm Rides, community members volunteer and engage in the Fleet Farming program. Such participation facilitated the exploration of Fleet Farmer's interactions with the community and events as a means of learning the explicit and tacit aspects of their organizational routines (DeWalt and DeWalt 2011, 1). Participant observation allowed me to gather information such as the topics/issues of Fleet Farmer's concern, participant's social identities, interpersonal relationships, racial representation within the group, and participant's attitudes about sustainability, environmental justice, race, class, and gender. Most importantly, participant observation helped me develop rapport and trust with Fleet Farming.

\section{Semi-structured and Informal Interviews:}

I also collected data using semi-structured interviews, which I recorded with a voice recording device (with participants' permission), and took fieldnotes to record any details that enhanced the accuracy of conversations and observed events (DeWalt and DeWalt 2011, 161). I conducted semi-structured interviews using an interview guide (attached in Appendix C) with 11 questions and associated prompts. Semi-structured interviews provide a systematic method of

\footnotetext{
${ }^{7}$ Fleet Faring's Facebook Page. "Join the Swarm!" https://www.facebook.com/fleetfarming/photos/a.520525571397407.1073741828.483586935091 271/1464756666974288/?type=3\&theater
} 
data collection but also allow the research participant some flexibility in answering questions (as compared to structured surveys). Therefore, this method increased the likelihood that all topics were covered and the informant has the ability to introduce an angle not foreseen by the researcher (DeWalt and DeWalt 2011: 139). These qualitative interviews, lasting 15-45 minutes, allowed me to develop detailed and holistic descriptions and explanations, integrate multiple perspectives, learn how participants interpret events and bridge intersubjectivities, and identify shared perceptions of reality (Weiss 1994, 9-10). I also conducted informal interviews in the form of conversations. These informal interviews took place at Swarm rides, during farming shifts, and while processing produce.

To maintain confidentiality, I offered to assign pseudonyms to the research participants, however all the participants preferred that their real names, rather than pseudonyms, be used.

Interview Sample and Recruitment:

In order to recruit interview participants, I used the theoretical sampling method, using my research questions to shape my selection of "key informants" (Fetterman 2010, 35; Bernard 2002, 182), that is, participants who have authoritative knowledge of Fleet Farming. Key informants for this study are the participants with whom I conducted the semi-structured interviews. These participants were those most frequently involved with the Fleet Farming activities - mainly paid employees and unpaid interns - and could offer more in-depth insight on the organization's goals as well as their own understanding of the group's work. I excluded the bi-weekly Fleet volunteers as participants in this study because of their less consistent 
contribution to the organization's work. I also excluded participants under the age of 18. Given the time constraints of this study, I did not include Parramore residents or Audubon Park farmlette owners into my participant sample.

In total, I collected 13 semi-structured interviews with 3 Fleet Farming employees and 10 interns, as well as 16 informal interviews in the form of conversation. My sample size included 9 more participants than I originally anticipated in my research proposal because I spent further time with the program in September 2017, which allowed me to collect more data. I had also originally proposed to use a flyer to recruit Fleet members (see Appendix D), however, simply attending intern work days allowed me to gather an appropriate sample and establish rapport simultaneously.

\section{Historical, demographic and theoretical analysis}

In addition to participant observation and interviews, I also analyze historical and United States census data, which provide a comparative analysis of the racial and socioeconomic contexts of Audubon Park and Parramore. In this study, historical data ultimately serve to expose the complex processes that generate patterns of inequality (Holifield 2001, 85). Historical analysis contextualizes the current situation in Parramore and frames the arguments in this thesis about Fleet Farming's approach to expanding their branch to a poorer neighborhood. I include information about some of the other local/governmental initiatives and developments taking place in Parramore, which I accompany with an analysis of local media. 


\section{Data Analysis:}

I transcribed each recorded interview verbatim into Word documents that totaled 121 double spaced, text-based pages of narrative data. I also collected 49 hand-written pages of fieldnotes. I coded these data in "chunks," searching for patterns and themes so that I could then triangulate interview data and my fieldnotes to categorize my findings within the contexts of group beliefs (Fetterman 2010, 40, 94-97). The main themes that emerged from my data include: education as quintessential, environmental justice as justice for the environment, class conscious, color- and gender-blind consciousness, Fleet has good intentions, idealistic visions of interconnected communities, and autonomy and agency for interns. An a-political trend in Fleet's sustainability and environmental justice ideologies, agenda and practice emerged as an overarching theme in my findings. Using triangulation, I connected these findings with data from historical, demographic, and media sources to understand the situation holistically from several angles, with the focus on the part that Fleet Farming plays in this issue.

\section{$\underline{\text { Ethics Approval }}$}

The UCF Institutional Review Board reviewed and approved my research on April 10, 2017. Before and during my research I was transparent about my role as a student researcher and the aim of my study. I informed participants that the purpose of my research was for my Honors in the Major thesis, and that my findings will be publicly accessible after my defense via the UCF library system and potential scholarly publications. I provided participants with an 
explanation of research (see Appendix B) and I answered any additional questions. I asked permission to use my observations, experiences, conversations, and interviews as data for this research. I made it clear that participation in this study is not required, nor is any individual who previously consented bound to participation, and that individuals may withdraw participation at any time. I carried out this process of informed consent verbally and recorded it before starting the interviews. To maintain confidentiality, I offered to assign pseudonyms to the research participants, however, all of the participants preferred that their real name, rather than pseudonyms, are used. I secured all the data collected and digital materials (such as recordings and typed notes) in a password secure USB. I also kept all physical materials (such as written notes and documents) in a secure location in my home. 


\section{THESIS OVERVIEW:}

\section{AN A-POLITICAL SUSTAINABILITY AGENDA}

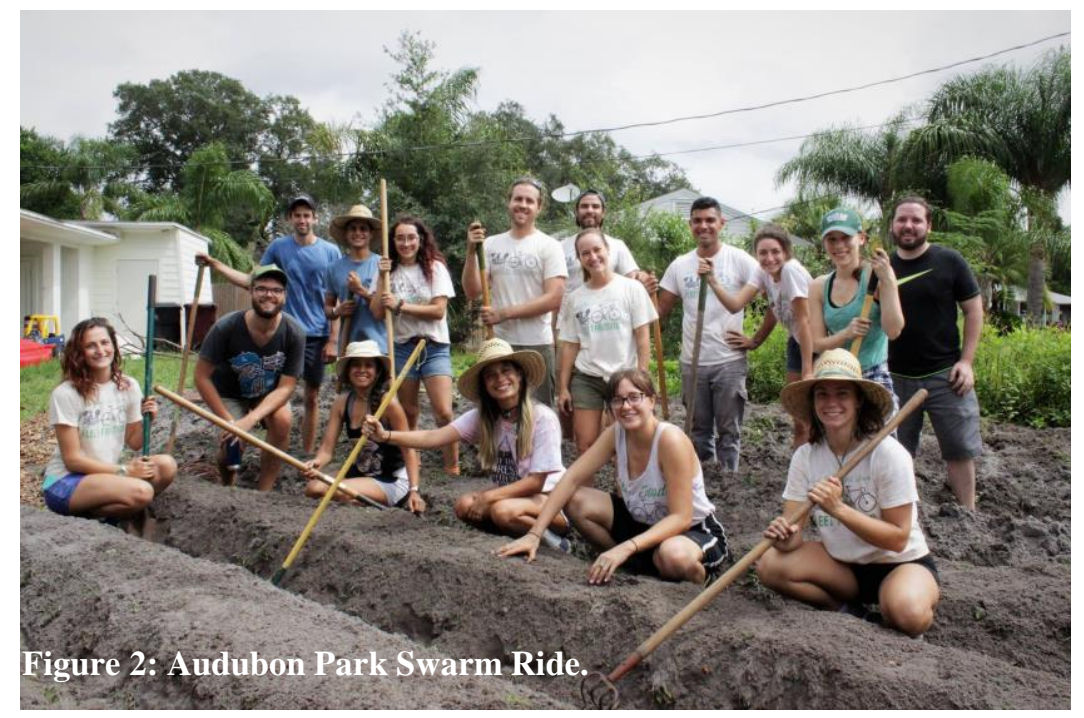

From bottom, going left: volunteer, volunteer, volunteer, volunteer, Caroline, Sigga. From top left: volunteer, volunteer, Meyer, volunteer, Leticia, 2017 intern (back) fall semester intern, Elise, volunteer, volunteer.
In Chapter one of this thesis, I provide evidence for Fleet Farming's understandings of environmental justice. My data reveal their implicit diversions from the political, in the sense that they conceptualize sustainability work as inherently apolitical. In this section, I also illustrate the

neoliberal potential of their assumptions about educational barriers and solutions in Parramore.

In Chapter one I argue that Fleet's tendency to focus on food or the environment itself, overlooks the structural inequalities that are at the core of the disparities in food accessibility in Parramore. In Chapter two I review Fleet Farmers' responses to how they believe Fleet is prepared to serve a marginalized community and show the assumptions that fuel their reasoning. I explain why their logic, that Fleet Farming is prepared because they have good intentions, may be problematic for the implementation of their program in Parramore. In this chapter I argue that good intentions do not address how Fleet Farming is prepared to deal with structural barriers, and therefore might serve to impede their program's effectiveness in Parramore. I then discuss Fleet Farming's 
economic discourse and how it focuses on money as the only barrier to food access. Here, I argue that race is a legitimate barrier to Parramore resident's access to the future Parramore Farmer's Market. In Chapter three, I provide an example of Fleet Farming's initial transition and opening event in Parramore and how the outcomes of this event are reflective of Fleet Farming's generally a-political approach to their Parramore expansion. I conclude by giving an overview of my general argument that Fleet's non-political stance is detrimental to their effectiveness and goals to address the complex political issue of food insecurity in Parramore. I will also consider my contributions to scholarship as well as avenues for future research in this area. 


\section{Chapter One: Environmental Justice as Justice for the Environment}

Throughout this study, I define environmental justice, as a discourse, practice or organizing framework that is "a political force capable of challenging the systematic causes of social and ecological injustices" (Faber and McCarthy 2003, 60). However, before delving into how Fleet Farming incorporates environmental justice into their agenda and practices, it was essential to establish how participants of this study understand environmental justice. My approach was to explore Fleet Farmer's conceptualizations of environmental justice and what the meaning of the concept was for each participant. Lee became the new director of Fleet Farming in May, but she has worked with the program for almost two years now. Lee expressed that her environmental justice goal for the Fleet Farming program is:

to bring fresh, local, organic food in these neighborhoods [...] where [people] have to live off of convenience store food because the box grocery stores don't see it as enough revenue versus the great need that these people have in regards to organic food. Just fresh produce is what they're looking for and what they need but they don't have it and they don't have access to it because of their level of income. And that's injustice.

Lee, who grew up in low-income circumstances and, for a long time, lived in inner city government project housing, was comfortable discussing the socioeconomic inequalities associated with food insecurity. Unlike most Fleet Farmers in this study, Lee gave a definition of environmental justice that is rooted in understandings of bureaucratic politics of environmental policy and the unequal distribution of environmental pollutants. In the context of food justice, 
she considers not only people's economic inequalities, but also structural barriers such as revenue-driven grocery stores that avoid low-income areas, leaving people with few food options. However, many Fleet Farmers engaged in a socially and politically neutral discourse of environmental justice, centered on the interconnectedness of social and environmental issues.

\section{“Trying to protect the planet”: The Limits of Deep Ecology}

Fleet Farming, and certainly other environmentalist groups, adopt a so-called deep ecology perspective, which is "concerned with an ethic of respecting nature and the inherent worth of other beings" (Naess 1989). Mayer, a new summer intern majoring in Environmental Studies at the University of Central Florida (UCF), told me that to her, "[e]nvironmental justice is caring about the longevity of [the planet] and understanding that everything is working together, even the most little, insignificant insect plays a central role [...] in living in cohesion, sustainably.” Mayer's view truly considers deep ecology ideologies about intrinsic value and promotes a sense of interdependence. I have observed that the language of a deep ecology ethic of intrinsic value and cooperation is common in Fleet Farming spaces. This language has generated a sense of belonging and importance among the interns, who have said they feel that Fleet values and considers them and their ideas. Discussions about Fleet's emphasis on community dominate every interview from this study; everyone expressed that a sense of community and "genuine care" was part of the reason for why they enjoy and remain active in the program. While this language of "cohesion" and universal care does build a strong sense of commitment and community among the interns and staff, it does not directly confront the socio- 
political aspects of environmental justice. This non-political ideological approach to understanding environmental justice may overlook the racial and economic inequalities that work to marginalize communities like Parramore. Sentiments like these take a "blind" stance, ignoring socially constructed inequalities that operate in reality, regardless of intrinsic value. Even though the intent of this ideology is holistic inclusion, consideration, and harmony with all beings, deep ecology perspectives prevented many Fleet Farmers from seeing the rooted structures of violence in Parramore.

Given the starkly different social context in Audubon Park compared to Parramore, food insecurity in Orlando is selectively unjust. Fleet Farming intends to address a selectively unjust environmental issue, but with a deep ecology lens, Fleet Farmer's frame justice as separate from structural violence. Parramore was an affluent community equal to their white neighbors before the construction of Interstate-4 (I-4), national desegregation, and the City of Orlando's struggle to integrate for a decade afterward (Porter 2004). Intentional gentrification and racial exclusion left Parramore residents at the margins of the city and 30\% of residents at or below the federal poverty line (see table 1$).{ }^{8}$ The city and past residents who were opposed to racial integration and equality did not respect the intrinsic worth of black people as residents lost their homes to economic development. When Publix, one of the largest supermarket chains in the southeastern U.S., refused to build a store in Parramore because of low economic viability, they absolutely considered the economic disparity in the neighborhood and disregarded residents' inherent value. Deep ecology perspectives do not address food insecurity as Fleet Farming intends. Deep

${ }^{8}$ Generated by “American Factfinder” factfinder.census.gov, accessed March 1, 2018. 
Ecology's a-political stance eliminates the extensive history in which food insecurity and oppression in Parramore festered.

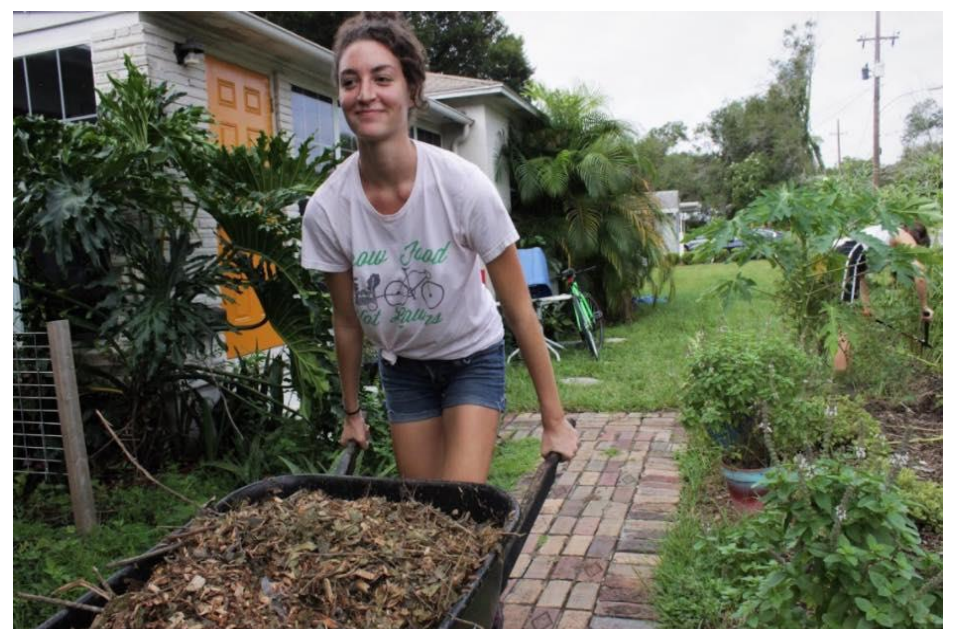

Figure 3: Elise farming at the Audubon Headquarters. (Photo by Fleet Farming)
Other Fleet Farmers described environmental justice as an engagement in a better relationship with and advocacy for the earth. Long-term intern Elise (see Figure 3), ${ }^{9}$ who is majoring in Environmental Studies at UCF and interns for the sustainability department there, described

environmental justice in terms of reciprocity by asking, “"what can I do for the earth because the earth has done so much for me?' So, giving back what the earth has given you and seeking justice for it." Chanelle, who is majoring in Interdisciplinary Studies at UCF and interned as an office manager this summer, corroborates this by saying, "Environmental justice is, since the environment can't speak for itself, we have to speak for it [...] so it's just trying to protect the planet." Chanelle and Elise both suggest that people have a responsibility to protect and restore the environment, which is a common theme in environmental activism and the deep ecology platform. ${ }^{10}$ Caroline, the longest-standing Fleet Farmer I met and current Fleet Farming Program

\footnotetext{
9 Fleet Faring's Facebook Page. "Hard work and a little hustle makes you stronger while building upon your character!" https://www.facebook.com/fleetfarming/photos/a.538932376223393.1073741829.483586935091 271/1553090811474206/?type=3\&theater ${ }^{10}$ For a detailed description of the deep ecology philosophy see: http://www.deepecology.org/platform.htm, accessed March 1, 2018.
} 
Manager, told me that she has been active with Fleet Farming for almost the three years of its existence because it helps to "reduce the effects of climate change" and links food production to ecology. She believed that Fleet Farming makes this link by "not dump[ing] toxins into our environment" and "finding different ways to grow food without harmful chemicals, pesticides, and fertilizers as a responsibility to where [those chemicals] end up in our soil and in our water." She further explained that the primary focus of the Fleet Farming model is to mitigate human impacts on the environment by reducing individual participation in the wasteful industrialized agricultural system.

In general, Fleet Farmers have described environmental justice as a move toward a reciprocal relationship with the earth and they focus on seeking justice for the environment, rather than a movement to enact justice for the humans who suffer from the environmental burdens. An environmentally focused stance on environmental justice, like the perspectives offered by Chanelle and Elise in particular, generally overlooks the people who live in those environments one seeks to protect. Furthermore, this positive and politically neutral language could mask unequal urban development and disable meaningful resistance to mainstream sustainability ideologies and practices (Checker 2011, 212). Fleet's expansion into Parramore is partly funded by the United States Department of Agriculture's Farmer's Market Promotion Program (FMPP), which allotted the City of Orlando $\$ 250,000$ to "help us to expand food access in neighborhoods that need it most" (Orlando City Hall 2016). The City of Orlando controls the FMPP and associated grant money, which is concerning because the city has historically utilized its power to marginalize the poor and people of color (Porter 2004). For example, in 1940 the city built a low-income housing project that destroyed 154 homes, despite an injunction filed 
against them by black property owners to stop the destruction of their homes. The City of Orlando built the project to house black residents who they forced out of what is now the Audubon Park area (Porter 2004, 309). So far, the city has dictated when Fleet would receive their $\$ 50,000$ of FMPP funds, where they could locate their new headquarters, and has taken the liberty to hire the new Parramore branch employees. Under a politically neutral framework, Fleet Farming is effectively allowing the city to more easily use the FMPP to subordinate their justicefocused goals by utilizing their seemingly a-political agenda to conceal unequal development. Furthermore, the politically neutral language used to conceptualize an "inherently equal" sustainability project undermines the possibility for Parramore residents or Fleet Farming to resist the city's unequal development plans.

\section{"You have to teach them to appreciate": Education as Solution?}

The narratives in my research also demonstrate beliefs about education as a barrier and solution to food insecurity in Parramore and food-environmental issues in general. When I asked the research participants how they thought Fleet Farming was implementing environmental justice into their agenda and practices, Fleet Farmers commonly referred to education as a primary way they do this. Chanelle said that a "big way that they're involved with environmental justice" is by "teaching people how to [garden] and showing them why it's important." Although Lee has a more socially focused idea of environmental justice than Chanelle, she corroborates and builds upon Chanelle's point by saying: 
In Parramore $[\ldots]$ and these low-income communities that we're going into, they [residents] have been living on convenience store food and boxed food and dehydrated, nutrient deprived food for so long that a lot of people don't know what to do with kale, they don't know what to do with Swiss chard. And it's not because they're ignorant, it's because they've had to survive off of other ingredients [...]. So there's a needed education component that Publix wouldn't be able to give to the everyday person anyway. That's part of engaging the community; you have to teach them to appreciate and to utilize the food. Andy, a summer intern majoring in Environmental Studies at UCF, understood environmental justice similarly to Lee, describing the unequal distribution of "pollutants and other environmental 'bads." Andy said that in terms of incorporating environmental justice, Fleet Farming is moving toward "expanding and spreading [...] to areas that are less financially stable, and that have a lot less food security." She explained that, in her opinion, Fleet Farming's goal in Parramore is to

bring a system like this to people who are in that food desert situation where they don't have access to healthy food. I think that's a super cool way to sort of expose people that maybe it just hasn't occurred to them that they could be growing their own food through a system like this and then educating people so they're able to take care of themselves more.

Andy's inference that Parramore residents might not know how to grow food is something other interns mentioned too. Mayer said that in many food insecure areas "people don't really understand that you can grow all your food in your front yard." Fleet Farming, considering 
themselves an innovative program, generally assumes most people who have grass lawns do not know how to farm in the way Fleet has modeled. However, this assumption does not necessarily explain why people in Parramore are food

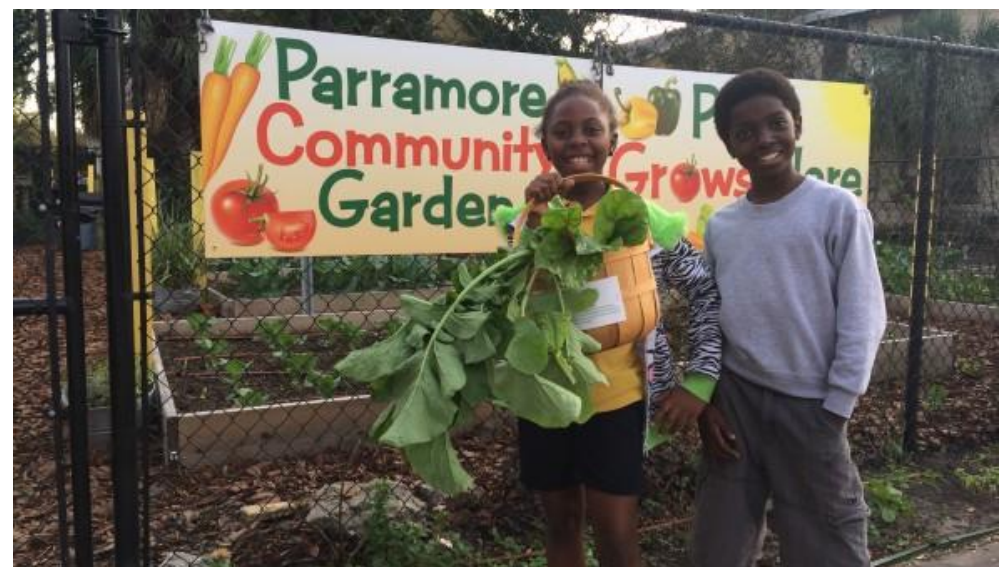

Figure 4: Children at the Parramore Community Garden (Photo by the City of Orlando)

insecure. Their depoliticized conclusions can in no way certify education as the solution or ensure the effectiveness of Fleet's educational model in Parramore. In addition to envisioning education of the community, Fleet Farming also seeks to educate its own interns. The organization's educational model has been effective in the well-to-do Audubon Park and especially for the interns, many of whom had never farmed before but eventually learned to take care of the farmlettes independently. However, a focus on education as a primary solution to attaining food security in Parramore disregards the fact that people are already practicing alternative gardening methods, such as the Parramore community garden (See Figure 4$)^{11}$ that began six years before Fleet Farming's inception. ${ }^{12}$ Parramore residents do not necessarily need Fleet Farming's educational services to "expose" to them to gardening, show them the importance of local farming, or allow them to appreciate fresh, hyper-local food. The assumption that education is a primary barrier and solution to food insecurity here detaches this issue from

11 City of Orlando Community Affairs and Human Relations. "The Garden." http://www.cityoforlando.net/oca/the-garden/

${ }^{12}$ For more information on the Parramore Community Garden see: https://communitygarden.org/find-a-garden/gardens/parramore-community-garden/, accessed February 12, 2018. 
the profound structural inequalities that caused such disparity. Additionally, commonly expressed ideas about Fleet Farming being an educational "tool," as Lee has said and many interns have explained in giving their reasons for joining, might unintentionally serve neoliberal purposes. What happens if Fleet Farming's particular form of "education" offered to Parramore does not improve food security? Will Parramore residents then be held responsible, yet again, for "their" poverty?

Considering the city's history of unequal development projects in Parramore, Fleet's apolitical sustainability discourse paired with the city-controlled FMPP could serve to mask the city's continued unequal urban development. Moreover, an educational discourse that disregards socio-political barriers may inadvertently place the responsibility of attaining food security upon those who would then be considered "able to take care of themselves." This tendency to focus on food or the environment itself, overlooks the structural inequalities that are at the core of these disparities in food accessibility (or lack thereof). 


\section{Chapter Two: Translating Good Intentions into Good Outcomes}

In this chapter I will analyze Fleet Farmers' narratives about how they believe Fleet is prepared to serve a marginalized community, and show the assumptions that underpin their reasoning. I explain why their logic may be problematic for the implementation of their program in Parramore, and explain my argument that good intentions do not necessarily mean good outcomes.

Chanelle is the only intern I met that worked solely in the office along with Caroline, who was the only office-based employee during this study. Chanelle's unique "behind-thescenes" work as an intern influences her viewpoint on how Fleet Farming is prepared to go into a low-income area:

They have good intentions, you know, they're not thinking about exploiting people or trying to make money. They've gone through periods where, before they were working here, they were just interns and they weren't making any money. Even when they were hired it wasn't like, “Oh, look at my amazing salary!" So they're not in it for the money, I think that's something that makes them a good fit for expanding and being ready to do what's necessary to fit in a low-income area.

Chanelle's response to my question that asked if and how Fleet Farming was prepared to go into Parramore highlights a vital characteristic of the program that each participant discussed: good intent. While Chanelle's focus as an intern was non-profit administration, other interns, who focused more on the ecological aspects of Fleet Farming, validated her claim. Valeria, a recent 
Valencia College graduate with an Environmental Studies Associate's degree and long-term intern described, "Fleet, in general, its heart is very pure. You know our goal isn't to make money or profit or gain popularity; we're just here to fundamentally change the world and figure out different problems for different people just by sharing knowledge and learning together, as a community."

When I first met Lee, she told me she was working around 60 hours each week for about a dollar a day, demonstrating her dedication to the success of the program. Elise, who has been with Fleet for nearly a year, told me she wanted to work with Fleet long-term because she sees the importance of such a program and feels loved by the "family" she has created with other Fleet Farmers. I observed that interning or working for Fleet Farming has more significance than just meeting a university credit requirement or "making money." For many, it is about gaining knowledge and creating a community of like-minded individuals. Thomas, a summer intern majoring in Environmental Studies at UCF, discussed "unity" as a major part of Fleet Farming's ultimate mission. He explained, "I think just the whole community kind of coming together is their main goal."

Participants viewed Fleet Farming's intent in Parramore as a selfless endeavor and they perceive Fleet's vision of building community as the driving force in this altruistic project. While I agree that Fleet Farming effectively fosters community in Audubon Park and that their intentions come across as honest, I argue that good intentions do not necessarily mean good outcomes. When I asked if Fleet Farming was prepared to serve Parramore and other marginalized communities, everyone referred to the program's honest intent, even if they 
recognized structural violence. Leticia, a recent Environmental Studies graduate from UCF and the new Farming Coordinator, identified gentrification as a barrier and explained:

We're not going to go there and take over all these things and develop; we're not there to help gentrify. We're there to help [Parramore residents] stay there and be able to fund themselves kind of thing. And then that's a way to kind of interact with the community, making them know that this is something for them too.

Because we are a non-profit, we're not getting tons and tons of money out of this. We don't want to exploit you. We just want to help you.

\section{Leticia's mention of}

gentrification shows that she, like Lee, understands some of the structural barriers in place in Parramore. While this recognition is essential, good intent remains the primary reason Fleet Farmer's gave for why they were prepared to go

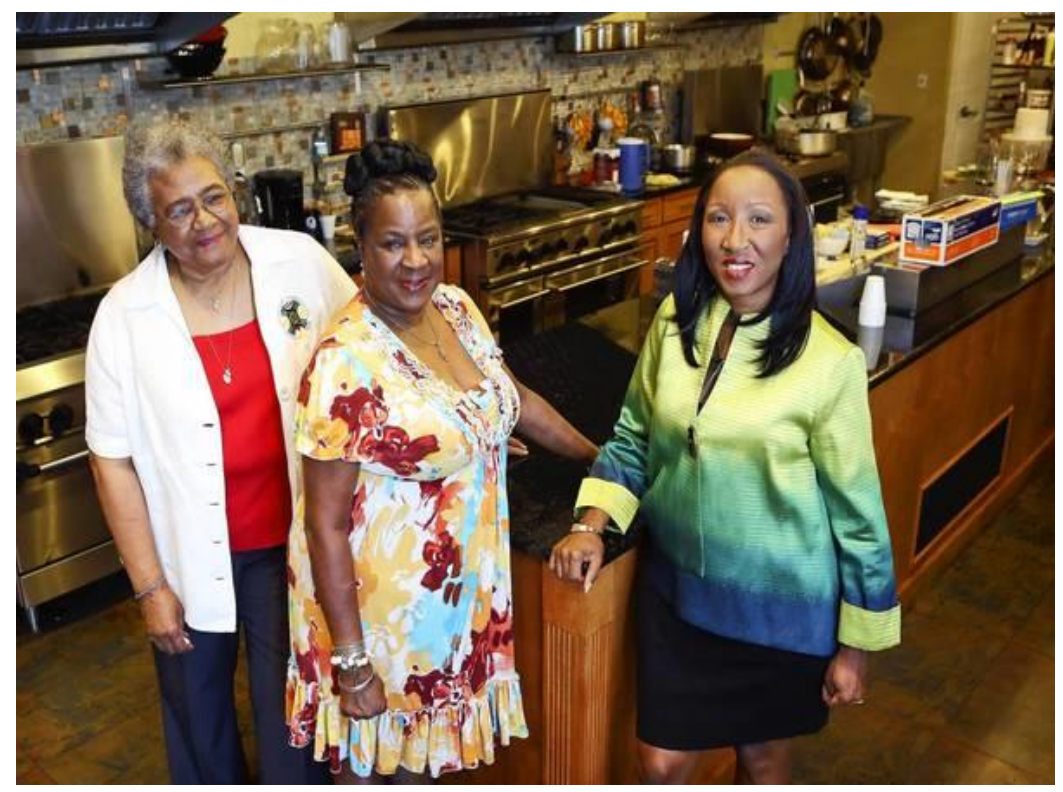
into Parramore. This reasoning Figure 5. Hebni (Left to right) Ellareetha Carson, Fabiola Gaines \& Roniece Weaver in test kitchen at Hebni (Photo by: Jacob Langston) could be problematic for Fleet's goals to create "unity" and share knowledge with the community as many mentioned. Fleet Farming, while focusing on intent as means of preparation, has not connected with key community members. Hebni Nutrition Consultants Inc. is a 
community-based, non-profit, nutrition education and resource center (see Figure 5).${ }^{13}$ Hebni has played a crucial role in advocating for African-American community health in Parramore, educating residents about chronic disease prevention and management since their establishment in 1995 (Matos 2016). While volunteering with Hebni in the fall of 2016, I found that they are also on the FMPP grant with Fleet Farming. Hebni's role in the FMPP is to teach residents about nutrition and healthy cooking with Fleet Farming's produce. At the time of this study, Fleet Farming had not contacted Hebni, even though they received notification of the grant award in October 2016. Instead of connecting with Hebni to learn how to effectively educate and organize the community—which Hebni has done for over 20 years-Fleet Farming has created their own vision of how they will educate and build the community. Leticia explained this vision:

I think that strengthening the community—especially a community that it is known for being dangerous-I think that, in the long term it might help with the statistics of [Parramore]. It'd be like, here we have the Fleet Farming organization who's working on this neighborhood that used to be terrible, but now that you're building community you start to feel that sense of like...that you're part of something, that you're important. And I think that that's really important for people to feel like they matter. And I think that, hopefully, within a month term it might help them-like crime rates go down.

${ }^{13}$ Jacob Langston. 2013 "Florida's slimming down? People in the trenches deserve credit." Orlando Sentinel. Accessed March 8, 2018. 
Leticia's vision of Fleet Farming "strengthening the community" and reducing crime rates, stems from the belief that Fleet's presence in the community will create unity. Crime in Parramore has been a major concern for the city for several years, especially since the city began to build the Orlando City Soccer Stadium ${ }^{14}$ that destroyed numerous homes during the construction process and is facilitating rapid gentrification. Historical data regarding the effects of desegregation in Orlando suggests that the high rate of crime is due to the dismantling of the black community, which was built on social solidarity and destroyed by structural violence (Porter 2004). For example, many of the subsidized housing projects, which Orlando Mayor Buddy Dyer heavily supports, ${ }^{15}$ have turned into high poverty areas ${ }^{16}$ due to a lack of social support and job opportunities. I suggest that these crime and poverty-ridden projects are also a way for the city to relocate the poor away from the growing metropolitan areas in Downtown Orlando, and centralize them in a location that gradually moves further away from the city. These federally subsidized ghettos are just one of the many structures put into place by the city to control and discriminate against the poor and people of color. Although some Fleet Farmers have recognized crime, economic disparity and gentrification as barriers, good intentions do not address the extensive history of structural violence that has caused these issues. Anthropologist

\footnotetext{
${ }^{14}$ See for example, an article in The Mane Land titled, "Violent Crime in Parramore Raises Game Day Concerns for Orlando City": https://www.themaneland.com/2015/1/7/7504917/violent-crime-parramore-raises-concernsorlando-city, accessed March 10, 2018.

15 See for example, an article in the Orlando Sentinel titled, "Orlando to build Parramore homes for low-income families": http://www.orlandosentinel.com/news/os-new-homes-affordablehousing-parramore-20170321-story.html

16 See for example, an article in the Orlando Sentinel titled, "Parramore Oaks affordable-housing project in Orlando faces hurdles": http://www.orlandosentinel.com/classified/realestate/os-bzfair-housing-20170206-story.html
} 
Paul Farmer $(2005,42)$ reinforces the necessity for analyses of structural and political violence to be "historically deep." This means that if Fleet Farming is to reduce crime rates, they must first understand that crime exists as a symptom of structural violence: it is the result the U.S.'s segregative culture and the nation's long history of exploiting, neglecting and intentionally marginalizing black communities, as well as a consequence of designating a central location in which the city has confined the poor and people of color. Therefore, I argue that these historical roots must be Fleet Farming's main consideration if they wish to lower crime rates, "build community," and acknowledge peoples' intrinsic value as they intend to do.

Fleet Farming's vision for their program in Parramore, now and for the future, does not thoroughly consider the problems Fleet Farmers mention such as crime, food insecurity, and financial disparity. Good intentions do not address how Fleet Farming is prepared to deal with these inequalities and therefore might serve to impede their program's effectiveness in Parramore. Without addressing exactly how they will strengthen a community that has suffered from historical oppression and especially without connecting with Hebni, Fleet Farming is overlooking the politics that control the problem of food insecurity.

\section{Colorblind but Class Conscious}

Though Fleet Farmers engage in a rather a-political discourse on food and environmental justice, they do consider the economic barriers Parramore residents face. Most interns were comfortable with discussing economic disparity, as this is a popular topic in Orlando media and a 
key aspect of food insecurity. Because of this, Fleet Farming has developed a plan to make their program "affordable" for low-income residents. Caroline explained that residents wouldn't have to pay anything for us to come a farm their land, they would just benefit from eating all of the food that they wish and you know, engaging in our Swarm rides [bi-weekly volunteer events] [...] And so, from all of that, the excess will then go to the farmer's market that is being completed in the grant as well. And at the farmer's market we will utilize the SNAP [Supplemental Nutrition Assistance Program] program. So within the SNAP program the community members don't have to use their own money, they use tokens to buy food and products. And they get double the amount of tokens on fresh produce.

Caroline's explanation of how Fleet Farming prepares to serve a low-income community is representative of Fleet Farming's larger economic considerations and plans. Every intern I interviewed seemed comfortable with answering questions related to income or brought up

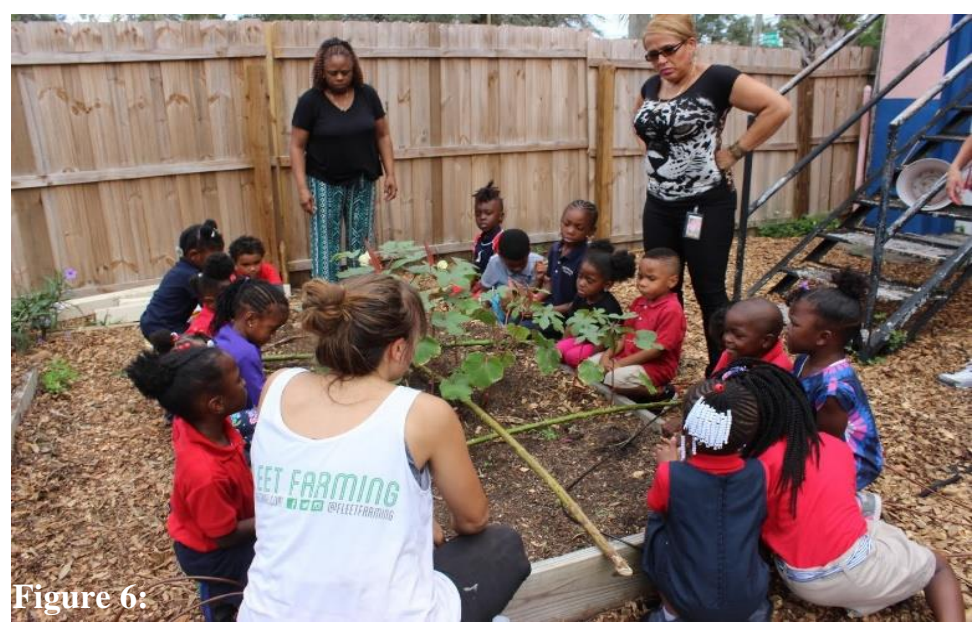

Caroline installing garden at Knowledge for Living. Working with Head Start program children (Photo by Fleet Farming) income inequality voluntarily. For example, Torre, a summer intern from UCF who also serves as an intern for IDEAS, said that she thought Fleet Farming's expansion to Parramore "would be awesome because I know that they're a really low-income neighborhood." Fleet's development of a discourse on economics, but not race, may be because the City of Orlando has 
normalized discussions of economic disparity in Parramore. A clear example is the Parramore Comprehensive Neighborhood Plan (PCNP), which was created by the city through collaborating with "residents, business owners, faith leaders, and other community members to identify recommendations for potential redevelopment sites, improve economic and business development policies, support the needs of children and education, increase housing opportunities, and improve public safety and quality of life." ${ }^{17}$ However, this economic discourse does not consider how racial inequalities related to environmental injustice occur whether a community is wealthy or poor (Lavelle and Coyle 1992)

Fleet Farming's economic plan intends for these SNAP benefits to provide equitable access to the future farmer's market and encourage residents to participate in this local food

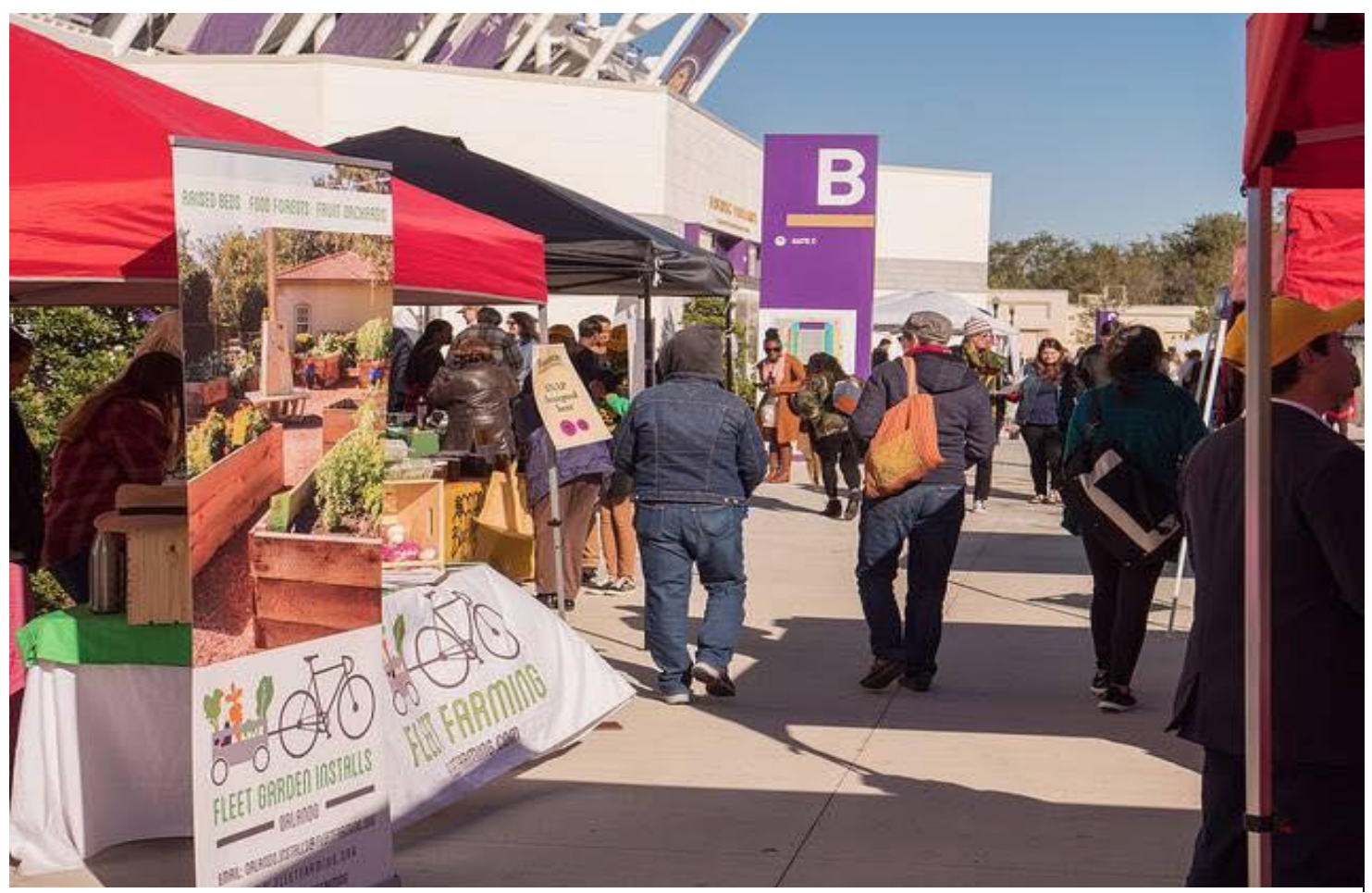

Figure 7: First Parramore Farmer's Market (Photo by Fleet Farming)

${ }^{17}$ See page 18: "Plan Introduction" http://www.cityoforlando.net/greenworks/wpcontent/uploads/sites/27/2015/01/PCNP-FinalDocument.pdf, accessed March 1, 2018. 
network. However, this discourse does not consider how race and class work simultaneously as barriers to access. The expense of farmer's markets not only makes them economically inaccessible, but also socially inaccessible, as farmer's markets seem to cultivate an exclusive upper-middle-class, cosmopolitan culture. I have observed that the farmer's markets in which Fleet participates, and those in Orlando in general, are mostly white spaces, where people can buy foods like grass-fed meats and vegan deserts, or artisan goods such as soaps and crafts. Though utilizing federal social services is one way to begin to address issues of inequity, "these programs operate in environments already characterized by forms of race and class exclusion" (Lambert-Pennington and Hicks 2016, 64). In a study on racialized food spaces, geographer Margaret Ramírez argued that "efforts to build more 'inclusive' community food projects in lowincome neighborhoods of color are not addressing the power asymmetries built into the projects themselves" $(2014,765)$ (see Figure 6).$^{18}$ The "culture of segregation," upon which many U.S. urban areas, including Orlando, are premised, "has manifested itself in the privileging of whites with superior and relatively safer locations, and the exclusion and confinement of blacks in undesirable enclaves" (Hanafi 2015, 412). Fleet Farming had not acknowledged how hosting the farmer's market in the Orlando City Soccer Stadium (see Figure 7) ${ }^{19}$ might unearth traumas related to how the structure itself facilitated recent gentrification that pushed out many blackowned businesses in Parramore. The Orlando City Soccer Stadium might be a comfortable place in Parramore for upper-middle class, whites, including Fleet Farmers. However, considering the

\footnotetext{
${ }^{18}$ Fleet Farming Branches 2017: https://fleetfarming.org/branches/parramore/

${ }^{19}$ Fleet Faring's Facebook Page.

https://www.facebook.com/fleetfarming/photos/a.538932376223393.1073741829.483586935091 271/1536725929777361/?type=3\&theater
} 
structurally violent and racialized history associated with the planning, development, and functioning of the stadium, it does not seem like a welcoming space for the black Parramore residents that the market intends to serve. Additionally, SNAP benefits can be problematic for vendors since they do not get much economic return on their goods or might have to invest in a special card reader for Electronic Benefit Transfers (EBT).

Therefore, while Fleet's economic plan is important, without considering what "access" means in a social, political, and economic sense, the organization is neglecting the holistic nature of the issue of access.

\section{"She was the leader": Gender, Race and Class}

My research questions for this study target the most prevalent inequalities that contribute

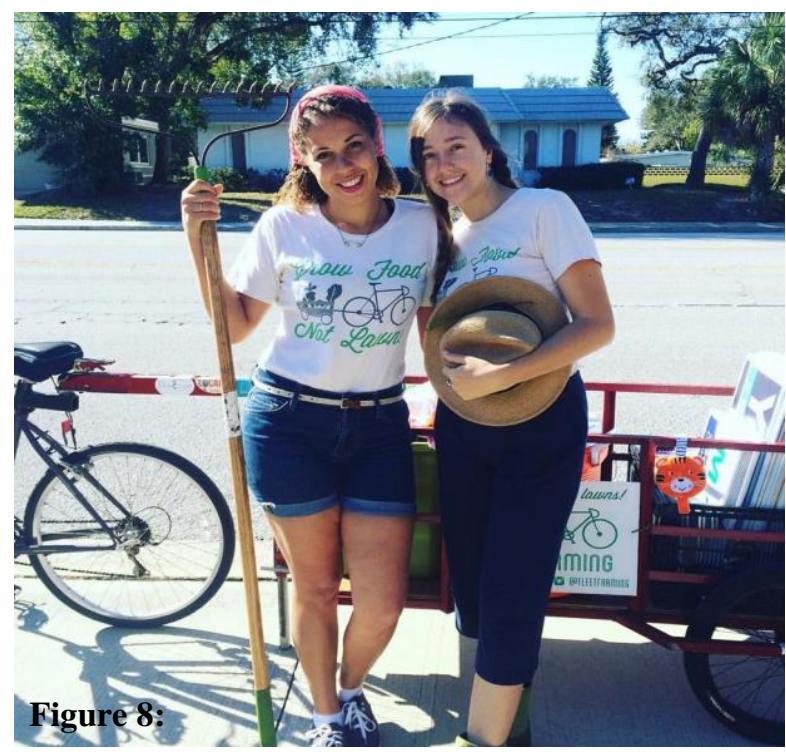

Lee and Caroline on a Swarm ride in Audubon Park (Photo by Fleet Farming) to food insecurity in this case. However, themes of gender naturally emerged, though in a very different way than race and class. At the time of this study, it was mainly women who had developed and represented Fleet Farming since its founding in 2015 (see Figure 8). ${ }^{20}$ Though the executive directors for Fleet's parent organization, IDEAS, have been mostly men,

${ }^{20}$ Fleet Faring's Facebook Page. "Starting a Fleet Farming Branch takes a lot more than time and money!"

https://www.facebook.com/fleetfarming/photos/a.520525571397407.1073741828.483586935091 271/1223981971051760/?type=3\&theater 
women have led the majority of the "on-the-ground" work and design of the program. For example, most interns at the morning shifts were always majority female. Lee explains how Fleet was developed by women during an interview: "Heather was kind of the warrior, she was the leader. She really started Fleet from zero, with the help of Chris [the founder of IDEAS], but Chris was getting into his job with the city [as Director of Sustainability]. [...] So she's the one who made the operation really what it is right now, at least the foundation of what it is."

Heather, who continued developing Fleet even after she and Chris separated, and other women dedicated to advancing Fleet's mission have been the main leaders for the program. Lee and Caroline both expressed a feeling of ownership and commitment to advancing the program, a sentiment they shared with other Fleet Farming leaders. While the almost all-male (save for one woman) IDEAS executive board oversees the approval of all financial decisions, Lee has the authority to make most of the decisions in the Fleet Farming program. For example, Lee might decide how to spend FMPP grant money, but the executive board must approve those decisions and allocate the funds. In addition to the all-female leadership "on-the-ground," Fleet Farming had a majority female intern group (see Figure 9). ${ }^{21}$ When I commented that women make up the majority of the leadership, Lee responded by saying,

When I look into someone's eyes, I don't see male or female anymore, I see a person that I want to empower - no matter what gender they are. I'm honored and proud to be a woman, but after a while it's almost like if we still have to keep highlighting that the program is run by women and it still has this stigma-

\footnotetext{
${ }^{21}$ Fleet Faring's Facebook Page. "Let's hear it for the female farmers out there!!" https://www.facebook.com/fleetfarming/photos/a.538932376223393.1073741829.483586935091 271/1564858730297414/?type=3\&theater
} 
whether it's in a negative connotation or a positive connotation-like, "Wow! It's run by women?!" And that's still a new fact that's mesmerizing to people [...] We have so much to do in micro-farming and we just need to do it togetherrepublicans, democrats, male, femaleit doesn't matter, we need to just do it and move forward.

Though I did not explore this further with any participants, it is clear from Lee's observations that the predominate presence of women in this organization was significant in their

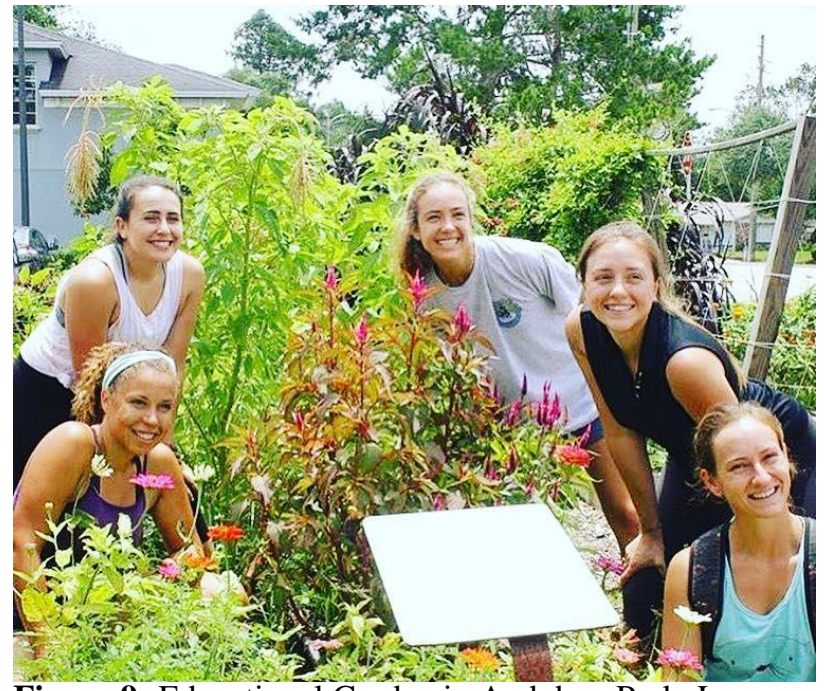

Figure 9: Educational Garden in Audubon Park. Lee (bottom L, Sam (top L), Andy (top R), Caroline (mid. R), Leticia (bottom R). (Photo by Fleet Farming)

experiences. Lee emphasizes that she does not discriminate based on gender simply because she does not "see" gender. While in her statement she meant to convey her non-discriminatory code of ethics, Lee's comment is reminiscent of the "I don't see color" rhetoric of "color-blind" consciousness. In the same way skin color and racism exists without racial consciousness, turning a blind eye to gender does not eliminate such differences and discrimination either. I agree with Lee, that we must move past our differences in order to accomplish sustainability goals, however a gender-blind approach may serve to exclude rather than include, which may have been the cause of the all-female leadership and internship trends.

This ability for Fleet to be "gender-blind" suggests a position of privilege as well. Environmental justice scholar and food sovereignty advocate, Vandana Shiva, argues that women are at the forefront of efforts to reclaim food security and advocate for environmental 
justice across the world (Shiva 2014, 2016). Shiva (2014), in her analysis of the gendered politics of food in India, suggests that like the environment, women fall victim to patriarchal forms of development, and that this shared victimhood leads women to take on the responsibility to protect nature. The vulnerability Shiva (2014) describes among women in India pertains broadly to women in underdeveloped nations, who are victim to Western forms of patriarchal development. Unlike the women in Shiva's analysis, none of the Fleet women indicated that they were motivated to participate because of a sense of shared victimhood with the environment. Perhaps Fleet Farming women's privileged position as (mainly) white, educated middle-class women, who have the spare time and interest in community volunteerism, motivates them to advocate for the environment rather than any personal experiences with environmental injustices.

Given that women are the primary Fleet Farmers, several questions arise from the brief examination of gender that emerged in my fieldwork: How might the socio-environmental challenges people in Parramore face differ according their gender? Does it matter that mostly women lead Fleet Farming in terms of how they engage (or not) with the Parramore community? Does food insecurity have different manifestations for men and women in Parramore? And if so, how might Fleet Farming approach these differences in their activism in this context? And more broadly: What is the meaning of access when one considers the ways in which race, class, and gender work together as social inequalities? These are valid questions for future research considerations focusing more closely on gendered effects of sustainability initiatives, and gendered experiences of food insecurity. 


\section{Chapter Three: Facing Political Realities through Engaged Anthropology}

Following my study, I decided to serve as a research intern with Fleet Farming, in order to better connect the organization to Parramore residents and community leaders. Through this engaged role, I work to facilitate Fleet Farming's understanding of the deep mistrust Parramore residents have of such programs and assist Fleet in developing a socio-environmental justice framework for their mission and practices. In this section, I will describe a situation in which Fleet Farming had to face the reality that their program in Parramore is highly politicized. The following description of Fleet Farming's first volunteer event in Parramore shows how their program is enmeshed in the structures of power that have existed in Parramore long before Fleet Farming arrived.

In late November 2017, I met with Lee at Fleet Farming's new headquarters in Parramore, commonly referred to as the Kaley Square Community Center (KSCC). ${ }^{22}$ The drive to the KSCC is fraught with historically unpleasant thresholds. A person driving into Parramore must first cross the segregating threshold, demarcated by a set of railroad tracks that thud and tear at car tires. Past the tracks, the conspicuous Division Avenue, another historically dividing line, then greets the driver. The final segregating barrier that a person driving into Parramore must pass is the I-4 underpass, which is constantly undergoing construction that cuts off different roads, changes traffic patterns, and creates a lot of noise, dust, and debris. Very near the segregated edge of Parramore, the KSCC is a long, white two-story building, formerly a church,

\footnotetext{
${ }^{22}$ For more information about the Kaley Square Community Center see: http://kaleysquare.org/\#About-Us, accessed February 27, 2018.
} 
situated in between two neighborhood streets. The KSCC has multiple rooms/spaces that the manager of the center, Demetrius, opens for different programs and groups that benefit the community. Fleet Farming and a church group were the only occupants of the space at the time so Fleet was donated the top floor of office space for free. In front of the KSCC parking lot is a little park with a short walking trail, littered with pine needles, a jungle gym set, fit for a small

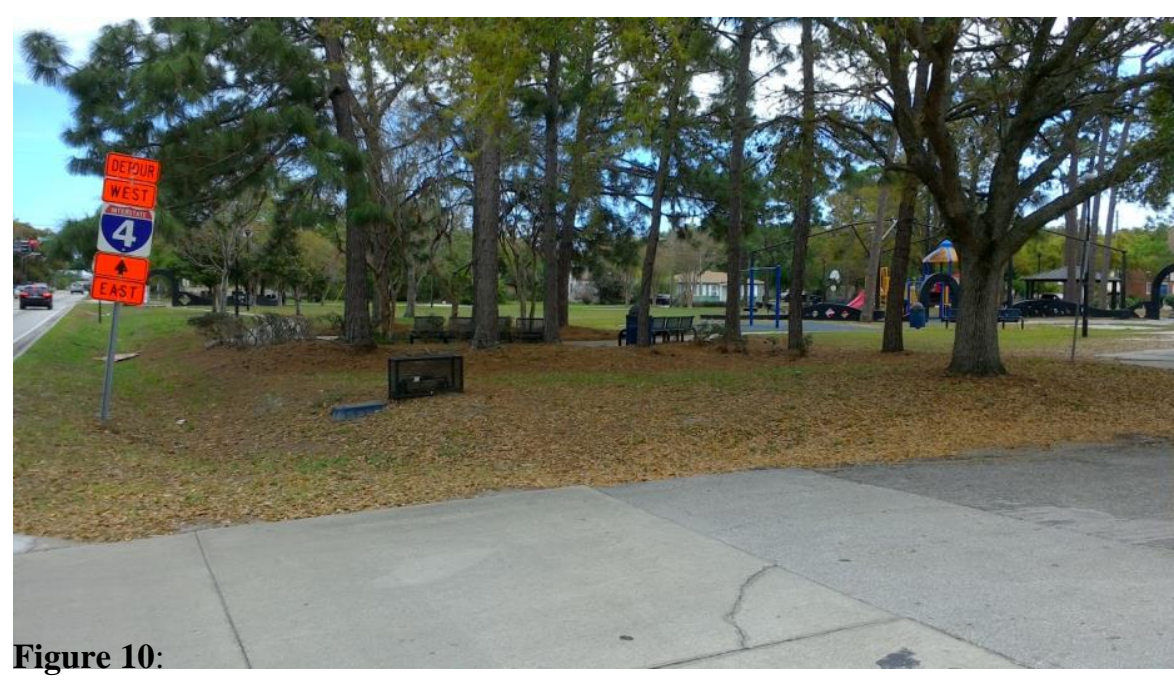

Kaley Square Park and I-4 Construction.

Perspective from KSCC parking lot (Photo by author) group of elementary

school kids, and an open

field, which some boys

were using for informal

sports games (see Figure

$10)$.

Lee met me outside of the KSCC and explained some of the future

farmlette installations she had planned for the area. On the south end of the KSCC and across the street is a grass lot lying empty next to a small yellow and gray house, which is timeworn and vacant. Pointing at the abandoned space, Lee told me, "We had that lot donated to us so we're going to have a pop-up bike repair shop and a gardening education center. And that house next door is going to be turned into a women's health center." The bike repair shop is part of the KSCC's new Cycles and Sprouts program that is a community-based agriculture and bicycle repair program that seeks to fill empty parcels of land in Holden/Parramore with bike repair 
shops and urban agriculture. ${ }^{23}$ Lee led me inside and upstairs to the Fleet office which had desks against every wall for interns to work on, a small kitchen stocked with snacks, and space for people to socialize and have meetings. Inside the administration room Caroline, Andy, Torre, and two other female interns, Sam and Sigga, who had continued interning from the summer, worked on their various projects for the new branch. They all greeted me in the Fleet Farming fashion, with hugs and comments such as, "I'm so glad you're here!"

Once they welcomed me to the new branch, Lee and I moved to a conference table in the kitchen where we talked about her plans for an event the next day and my role as a research intern in the spring 2018 semester. Lee told me, "I anticipate around 200 volunteers from Orlando City Soccer Foundation and Orlando Health," since both funding organizations, she thought, would want to be publicly recognized for their financial contributions to the Fleet program in Parramore. She planned to have Fleet interns, the Orlando City Soccer Foundation and Orlando Health volunteers help Demetrius repaint some rooms for new youth programs he was adding, which are also part of the PCNP. If time allowed, Lee wanted to install a farmlette somewhere around the KSCC building or in the small field in the park next door. Caroline soon joined us to take detailed notes about Fleet Farming's goals in Parramore and discuss how I could help. To accomplish these goals, Lee explained that she wanted me to compile a survey and canvass the community to answer particular questions. Lee gave me specific questions to ask, saying, "We want to know: What is their favorite vegetable? What foods do they usually eat? Where do they buy their food? How much do they spend on food? Are they employed? Do

\footnotetext{
${ }^{23}$ For more information on Cycles and Sprouts see: http://kaleysquare.org/programs/cycles-andsprouts\#About-Us, accessed February 27, 2018.
} 
they rent or own their homes? What is their primary form of transportation? And do they feel safe in their neighborhood?" Caroline added, "And maybe you could ask if they spray their lawns [with pesticides]." They wanted me to collect each piece of information so that they could establish baseline metrics to measure Fleet's impact in Parramore over time.

At the first volunteer event the following day, Fleet Farming was ready to receive community members, eager to learn, and 200 volunteers from the funding organizations, Orlando City Soccer Foundation and Orlando Health. Caroline set up a table with stacks of information pamphlets, flyers, plants, farmlette maps, and maps of Parramore to provide education to anyone who came. A cold front was coming in and the chilly wind kept blowing the pamphlets around and shaking the tent, which was protecting the materials from the light rainfall. Though Lee anticipated over 200 volunteers, the only volunteers to show up were me, Lee, Caroline, Michael (the Parramore branch manager), and about 11 other Fleet Farming interns. We spent the day renovating a room upstairs, which the KSCC planned to use as a youth dance studio, and painting rooms downstairs, in which Demetrius planned to host youth tutoring programs. I painted the downstairs tutoring space with Demetrius, who moved to Parramore in the early 2000s with his family. Demetrius and I engaged in a long conversation about some of the influential black leaders in Parramore, the racialized history of Parramore, devastating effects of segregation and desegregation in the black community in general, and Demetrius's dedication to sharing this history with his children. The conversation, which continued through the 4 hours we painted, was the most I had ever discussed racial inequality in the U.S. and in Parramore while working with Fleet Farming. 
The aim of the event was to engage people from the funding organizations in the very activities that they provide money for Fleet Farming to do, and to attract Parramore residents who Fleet assumed would want to be involved. Despite these optimistic intentions, no volunteers or visitors from Orlando City Soccer Foundation or Orlando Health came, none of the educational materials were handed out, and no farmlette was installed. One Parramore community member did come and was interested in helping, but he left after he learned that he

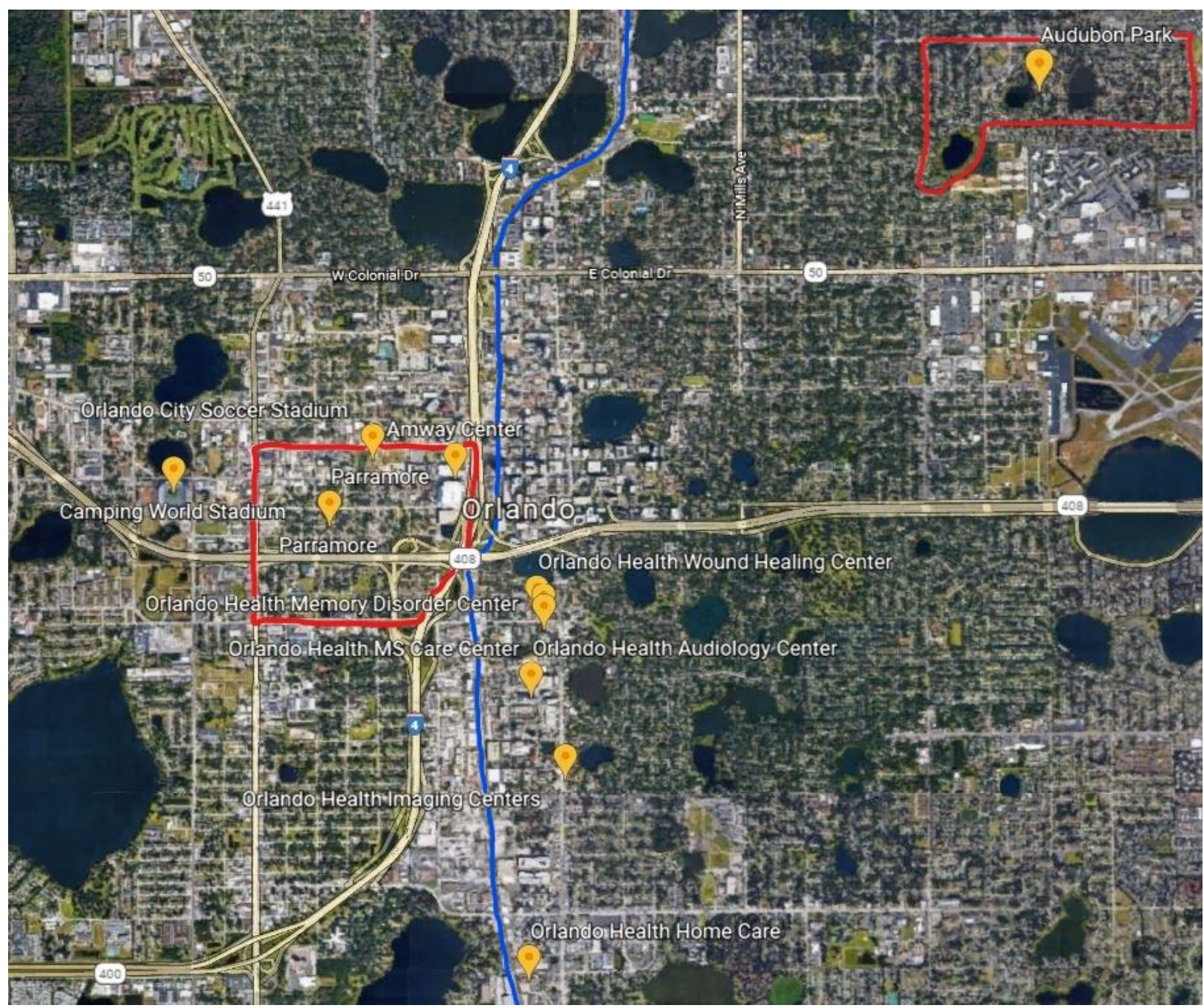

Figure 11: Map of Downtown and West Orlando.

Red Line: Parramore and Audubon Park boundaries. Blue Line: Railroad tracks. Beige Line: I-4 and 408 Toll Road. Yellow Location Bubbles: Orlando Health and stadiums. 
would not be paid. There was also no discussion among Fleet Farmers about these unintended results of their first community event. Fleet Farming expressed the intent to engage the community but their intentions only helped them secure funding from organizations who are not concerned with the social sustainability of the project. Having not shown up to even visit, let alone volunteer, Orlando Health and Orlando City Soccer appeared uninterested in participating in the implementation and functioning of Fleet Farming's program. I question the extent to which these organizations are truly dedicated to building social and ecological sustainability in Parramore like Fleet, especially given the discriminatory trends of their past actions. Orlando City Soccer promised Parramore residents jobs once they opened the new stadium, but instead worked as a catalyst for gentrification. Additionally, there are no Orlando Health medical facilities that extend west, past the railroad tracks and I-4, into Parramore, and the multiple other historically African American communities in West Orlando (see Figure 11 above). The political reality Fleet Farming had to face was that Orlando Health and Orlando City Soccer Foundation are funding an innovative and popular "sustainability" project, but not making an investment into the health and wellbeing of individual community members.

Fleet Farming's sustainability discourse neglects to acknowledge how race and structural violence directly relate to their program in Parramore. Cultural anthropologist Melissa Checker (2011) reveals that such a-political sustainability discourses overlook and sometimes perpetuate socioeconomic inequalities since the a-political assumptions of sustainability ignore the historical, social and political contexts of communities. This politically neutral language of sustainability, she argues, might be co-opted by organizations/programming (such as the PCNP, Orlando City Soccer, and Orlando Health) to mask unequal urban development and disable 
meaningful resistance to mainstream sustainability ideologies and practices (Checker 2011, 212). Without understanding the deeper socio-political structures of power that effectively keep Parramore impoverished, Fleet and others might dismiss any resident protest of Fleet Farming's food sustainability initiatives. For example, reminiscent of the I-4 development project, "urban rejuvenation" rhetoric about the economic benefits of the Orlando City Soccer development (and others) undermined Parramore resident's forceful opposition to the stadium. Parramore resident's assertions that the City of Orlando has a "long history of ignoring the African-American community and taking advantage of minority residents" (Cantone, 2013) were neglected by the city planners and the stadium was built. The job opportunities, the income the stadium would collect, and the overall economic "rejuvenation" the stadium might bring to the Parramore and Downtown Orlando areas, undermined resident complaints of gentrification and exclusion from the stadium itself. Orlando residents have heavily criticized the city in the media for gentrifying and degrading Parramore ${ }^{24}$ (Cherny 2015, Kelly 2015) yet, many key officials fail to address these issues, but instead defend their "urban rejuvenation" efforts. Orlando Mayor Buddy Dyer, for example, when asked to respond to Parramore's gentrification crisis (a result of entertainment complexes and arena developments he approved) said that he does not "necessarily call that gentrification just because [they're] improving the neighborhood." ${ }^{25}$ During a political debate for

\footnotetext{
${ }^{24}$ See article in West Orlando News titled: "West Orlando News Slammed For Criticizing Jericho March": West Orlando News, June 21, 2013 http://westorlandonews.com/west-orlandonews-slammed-for-criticizing-jericho-march/

${ }^{25}$ See Orlando Weekly article: https://www.orlandoweekly.com/orlando/orlando-mayor-buddydyer-muses-on-the-past-the-future-and-the-departure-of-orlando-weeklys-billymanes/Content?oid=2401913
} 
county commissioner in May 2017, current county commissioner of Parramore, Regina Hill, responded to the topic of gentrification by spinning it in a positive light saying,

Actually, I don't find [gentrification or urban development] a dirty word [...] we have to be responsible with urban development and gentrification. I mean that I don't think that any community deserves a community that is full of hopelessness and despair and poverty. ${ }^{26}$

Both Mayor Dyer and Commissioner Hill boast about their efforts to "rejuvenate" Parramore, which has included increasing subsidized housing and expanding metropolitan development past the I-4 barrier. These efforts have intensified gentrification and created more "slum housing," which tend to be riddled with mold, situated near

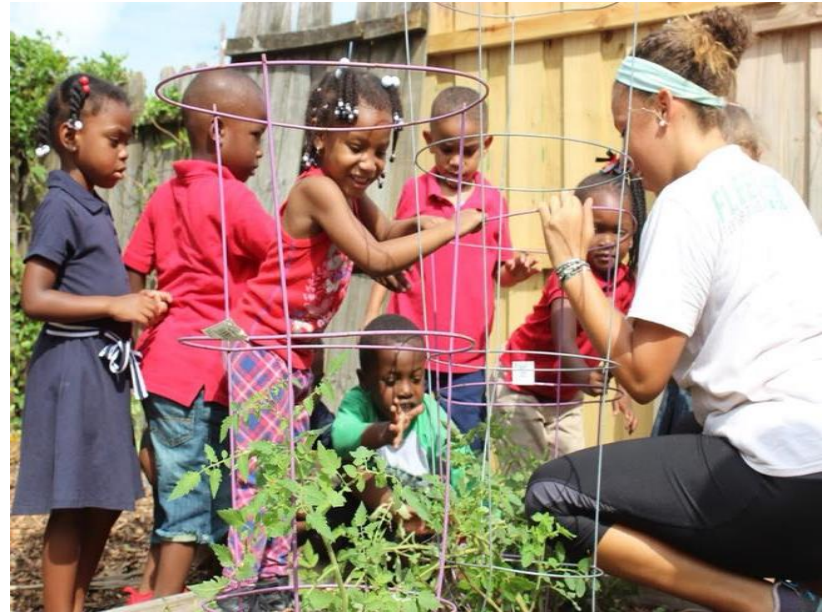

Figure 12: Lee installing garden at Knowledge for Living with Head Start program children (Photo by fleet Farming) highways, bus depots, superfund sites, and places where people suffer from higher rates of pollution- and nutrition-related illnesses. ${ }^{27}$ Despite these problems, Orlando City Soccer and other developers continue to defend their projects with the rhetoric of "urban rejuvenation." How

\footnotetext{
${ }^{26}$ See Orlando Weekly article titled "Three Orlando city commissioners fight to keep their seats and fend off a slew of candidates in a contentious race": https://www.orlandoweekly.com/orlando/three-orlando-city-commissioners-fight-to-keep-theirseats-and-fend-off-a-slew-of-candidates-in-a-contentious-race/Content?oid=8182380

${ }^{27}$ See Huffington Post article titled, “Even Breathing Is A Risk In One Of Orlando's Poorest Neighborhoods": https://www.huffingtonpost.com/entry/florida-poor-black-neighborhood-airpollution_us_5a663a67e4b0e5630072746e
} 
might Fleet's program, as environmentally sustainable and altruistically intentioned as it is, serve similar purposes? Geographer Catarina Passidomo (2014) argues that even in cases where organizations/programs like Fleet begin with goals to address issues of food justice, they may not be able to sustain these goals because of the necessities associated with meeting the priorities of funders and maintaining economic viability. Therefore, it is appropriate to ask what Fleet Farming's affiliation with organizations that contributed to poverty in Parramore could mean for their work there (see Figure 12). ${ }^{28}$ Could these affiliations serve as a barrier to Fleet Farming's goals for community engagement and education? What makes Fleet different from the organizations that support them? Is it possible that, even with good intent, Fleet will facilitate further gentrification? Such reflexive questions for Fleet might be more pressing than the survey questions Lee proposed, especially given the absence of community engagement and education in the first volunteer event. Fleet Farming faced the reality that their program in Parramore is highly politicized. This reality leads back to Ramírez's $(2014,765)$ argument that “without having addressed the power asymmetries built into the project itself, it will continue to struggle to build participation until these power imbalances are addressed." Fleet Farming failed to recognize the deep mistrust Parramore residents have toward organizations like Orlando Health, who remain "safe" on the east side of I-4 and the railroad tracks (i.e. the Downtown/Audubon Park area), where they have clustered their "West" Orlando facilities. Historical traumas associated with racial segregation and displacement, often facilitated by governing bodies and non-profit organizations, might play a role in why almost not a single resident from Parramore came to volunteer or learn about the program. Fleet Farmers, especially Lee who, after this

${ }^{28}$ Fleet Farming Branches 2017: https://fleetfarming.org/branches/parramore/ 
event, asked me how Fleet Farming can prevent further gentrification, faced the reality that securing project funding and providing financial incentives to encourage residents to buy produce does not dismantle every barrier. Without thoughtful community engagement and holistic understanding of this socio-environmental issue, the Fleet Farming program cannot operate, especially since it depends on community involvement. 


\section{CONCLUSIONS}

This thesis has examined if and how Fleet Farming considers peoples' varied racial and socioeconomic backgrounds when constructing their agendas and implementing sustainability projects in Parramore. I have argued that Fleet's a-political approach to their program in Parramore is detrimental to their effectiveness and goals to address the complex political issue of food insecurity. My data show that Fleet's non-political understandings of environmental justice serves as evidence for their implicit diversions from the socio-political issues that are at the core of the disparities in food accessibility in Parramore. Narratives in my study further illustrate the neoliberal assumptions held by Fleet Farmers about educational barriers and solutions in Parramore. These assumptions shift the responsibility of poverty on those who are intentionally marginalized by structures of violence. My findings reveal an underlying theme of good intentions in Fleet Farming's methodology and discourses, which I argue prevents them from effectively addressing the factors - including racial and socioeconomic inequalities, structural violence, and power asymmetries — of Parramore's food insecure conditions. Though Fleet Farmers engage in a class-conscious discourse, the outcome of Fleet's first community volunteer event demonstrated how important it is for them to consider the complexities of food insecurity in Parramore, which this thesis has outlined.

Though I was originally also inquiring about racial, ethnic, and socioeconomic representation within Central Florida environmentalism, the timing of my fieldwork and Fleet Farming's transition into Parramore guided my analysis down a different path. Themes of racial and economic representation and injustice, as they relate to sustainable initiatives in West 
Orlando, became clearer in the data I did and did not collect. Throughout my fieldwork, it was striking that none of the research participants discussed or even mentioned race as part of this issue. This finding is concerning given how racial inequalities intersect with food and agriculture in myriad ways (Guthman 2008). Fleet Farming is coming from a community of predominantly white residents and has an organizational makeup of people who mostly identified as white or of European descent. None identified as black/of African descent, yet Fleet Farmers are going into a community where most residents are African American or black. Julie Guthman (2008) argues that the absence of racial diversity in alternative food spaces reinforces the rhetoric of "if they only knew." Fleet Farming's assumption that people in Parramore “don't really understand" how to grow their own food might be due to Fleet Farming's low level of diverse racial engagement and participation within the organization itself, thus limiting their perspective on the issue. This lack of acknowledgment of the role of race is also troubling especially since the City of Orlando, which has caused and permitted so much racially charged violence (Porter 2004), is a significant actor in the FMPP. My research also brings attention to the black community's deep mistrust of the political systems in Orlando that have continuously worked against them.

In light of my findings, I argue that it is likely that race will be a significant barrier that Fleet Farming will continue to face in Parramore. However, given their intent to be inclusive and a positive force in the community, their neglect of discussions about race or political inequalities may also be interpreted as a way to avoid sensitive issues and perhaps distance themselves from oppressive institutions and developments. As Lambert-Pennington and Hicks point out (2016, 65), despite environmental justice actors" "best intentions" to address equity and access, this effort can only go so far in challenging the association between whiteness and alternative food 
systems. Likewise, Mark Schuller (2012) suggests that even well-intentioned individuals and charitable organizations, such as non-governmental organizations (NGOs) and non-profit organizations, face structural barriers related to meeting the requirements of funders. For Fleet, these structural barriers are also a result of the power asymmetries and inequalities existent within the City of Orlando's general "rejuvenation" plan for Parramore. While avoiding the political may help Fleet Farming's media "image" and help them secure funding, it is not likely to help them achieve the food justice, sustainability, and social rejuvenation goals they have for the program in Parramore.

My research therefore reveals that Fleet Farming lacks engagement in the politics of their food justice oriented program. I argue that their non-political stance is detrimental to their effectiveness and goals, especially since the nature of the problem the organization aims to address is inherently political. 


\section{SIGNIFICANCE}

This research contributes valuable knowledge to the field of anthropology, in general, as it considers issues of race and class as interrelated. Rather than understanding race and class as separate domains of inequality, I consider how race and class work simultaneously to reproduce structures of inequality in Parramore, and draw attention to the race-blind approach and effects of Fleet Farming's work. I have also situated my research within the field of public and engaged anthropology, with the goal to "rupture the status quo" (Besteman 2014) by sharing my results with the NGO, which in turn resulted in changes in the organization's approach. Therefore, while I sought to maintain scholarly distance during my data collection and analysis, my work ultimately seeks to facilitate the use of research data for improvements of community projects, and public policies. My findings also add to the growing scholarship about NGOs that provide critical analyses of the approach and effects of humanitarian work.

Related to NGOs are questions of urban development. In this domain my research contributes to anthropological studies of development, working toward a "new theory of practice and practice of theory," which is an engagement with complex theoretical frameworks, collection of significant ethnographic data, and commitment to political practice (Escobar 1997, 510). This research and my continued work as a Fleet research intern, seeks to answer questions in a way that engages anthropological theory and methodology. Schuller (2012) argues for a more critical analysis of NGOs that go beyond ideal classificatory schemas such as "local" or "progressive," and focus on NGOs' actions, and the social impacts of these actions (181). Similar arguments are suitable for analyses of sustainable development. However, the findings from this study suggest 
that scholarly analysis should not make assumptions about the intentions or outcomes of sustainable developments and initiatives, as I have demonstrated that Fleet's positive intentions to help Parramore have not translated into positive outcomes for the Parramore community. Fleet Farming's well-intended but a-political plan to expand into Parramore has inhibited Fleet's understanding of the historically deep roots of food insecurity there, which prevented them from engaging with the community on their first volunteer day. Thus, my research is significant in that it advances critical anthropological analyses of non-governmental, non-profit, and other community service-oriented organizations and projects aimed at environmental sustainability goals. This study shows engaged anthropological research and utilizes perspectives from the anthropology of development to contribute findings and propose solutions to environmental injustices.

My thesis engages theories of political ecology and structural violence to frame food insecurity as a product of structural racism, political violence, and economic exclusion. "Food security is a concern at international, national, household, and individual levels" (Gezon 2012, 124), therefore, I also situate my work within the context of a broader, "global food crisis.” My argument for how Fleet Farming should respond to this crisis is guided by anthropologists David Himmelgreen and Nancy Romero-Daza's (2009) argument that efforts to solve global food insecurity must be firmly grounded in local realities. Furthermore, this research is significant to anthropology and other social science fields, such as public health and geography, because it challenges the way social scientists define and utilize the category of "food desert." The word "desert" implies that this is a natural phenomenon (a part of the natural landscape), and therefore this connotation may result in the naturalization of "food deserts" as a presumably inevitable or 
"natural" aspect of urban living. Yet, in this research I have shown that "food deserts" are not a naturally occurring circumstance, but, in fact, a symptom of deeply rooted structures of inequality and violence, and further maintained by the race-blind approach of Fleet Farming's agenda and practices. I urge scholars to question and redefine the meaning of "food desert," since "limited access to fresh foods" goes beyond having limited financial means to buy fresh foods, and encompasses limited socio-political access to food. This thesis therefore calls for social science research to take a more critical approach to understanding global crises and responses related to food and environmental sustainability.

The complexity of factors I have presented in my thesis reveals a need for studies on sustainability, food, and environmental justice to be situated within the socio-political contexts of the United States, and focused on local approaches to interventions. Elyes Hanafi urges environmental justice scholars to "incorporate their findings within a historical framework that acknowledges the racialized nature of American social and economic institutions" (Hanafi 2017, 412). By framing my work within the context of the U.S., my research fills this gap in knowledge by exploring and directly addressing current injustices related to food and sustainability in urban areas.

\section{Engaged research with Fleet Farming}

I consider this project publicly engaged and define it as "anthropology in use," a more inclusive and relevant to present-day concerns conceptualization of anthropology (Rylko-Bauer et. al. 2006, 187). Anthropology in use situates my work within a continuum of anthropological 
practice or applied scholarship, and allows me to balance the extent which I integrate action into my theoretical analysis. I recently found that during its initial transition phase into Parramore, Fleet Farming encountered several barriers and has worked to build equitable solutions. Since I began the Fleet Farming internship in November 2017, I have had the opportunity to discuss my findings with Lee regarding the gaps and limitations in Fleet Farming's engagement with environmental justice discourse and practices. I have shared the demographic and historical data that provides context for the social, economic, and political conditions in the community, and my theoretical analyses of how Fleet Farming engages in the discourse and practice of environmental justice. Since the completion of this study and the first volunteer event, Fleet Farming is making efforts to better connect with the community and improve their program. I was encouraged to see that on the first intern on-boarding day in early January 2018, Fleet Farming initiated the largest and most diverse - in terms of race, ethnicity, sex, and educational major/occupation - intern group they had ever had, and the most diverse group of Fleet Farming participants, in general, I had seen. Internship positions before the move to Parramore were for farming only, with the exception of Chanelle's administrative role. However, Lee has expanded the internship positions to include grant writers, blog writers, business interns, administrative interns, garden installation and farming interns, digital media interns, and, my role, research interns. The expansion of the internship program and Fleet's increasing presence on the UCF campus (where Elise, through her internship with the UCF Sustainability Initiatives department, has been installing raised bed gardens) has facilitated this growth in internal diversity. Additionally, some interns were aware of my research project and immediately connected with me to express their concerns about gentrification. Significantly, many asked how they can help 
make connections with the community. Several interns have begun to support Parramore businesses by going to locally owned barber shops or convenience stores, for example. As a research intern, I mostly work to gather relevant data for the other intern teams. For example, I work with the blog writing team on incorporating themes of socio-environmental and racial justice into their blog posts. ${ }^{29}$ However, as a blog writer, I respect Fleet Farming's requests to address injustices related to their program without assigning blame on the funding organizations (e.g. Orlando Health and Orlando City Soccer) who commit these injustices. Though I strongly believe that Fleet Farming, with its environmental justice goals, should push back against oppressive entities, I also understand the predicament and their preference to not sever relationships with funders of their long-term work in Parramore. I also help the business and grant teams with gathering accurate social and economic data. Lee now encourages interns to incorporate themes of environmental justice in their work by highlighting instances of socioenvironmental inequity, and considering how Fleet may be able to directly address said inequity. Torre (a continuing intern), Marie (a new intern), and I collaborate on writing weekly blogs. Lee and I work closely to conduct interviews with local activists and leaders, while the digital media team video records and edits the interview clips. Lee conducted the first of these interviews with Lynn, an activist who helped found the Parramore Community Garden and fights against

${ }^{29}$ See, for example: https://fleetfarming.org/ace-school-seeding-event/ 
structural violence in Parramore, ${ }^{30}$ and Aminah who founded Knowledge for Living ${ }^{31} 32$ in Parramore, helping residents with services such as financial management and nutrition education workshops. We are planning our next interview with Hebni, in which we will focus on their experiences as nutritionists and community activists in Parramore and greater Orlando.

After moving to Parramore, it became necessary for Fleet Farming to confront and address the social, political, and economic realities that have resulted in Parramore's state of poverty. Their good intentions have evolved into appropriate goals, and their ideas of environmental justice now include the social justice aspects of the concept. The diverse new intern group has broadened Fleet Farming's perspective on the multifaceted issue of food insecurity, helping Fleet to create socio-environmental equity. Still, Fleet Farming is facing significant mistrust from the residents themselves, as they are concerned about the effects this program might have in their neighborhood. Nevertheless, the organization's new direction, in part resulting from this engaged anthropology research, offers a cautiously promising outlook.

\section{$\underline{\text { Future Research }}$}

\footnotetext{
${ }^{30}$ See for example Orlando Sentinel article titled, "Parramore leader sues Orlando over health problems at low-income housing project": http://www.orlandosentinel.com/news/local/osorlando-housing-project-health-lawsuit-20150702-story.html, accessed February 2, 2018.

${ }^{31}$ For more information on Knowledge for Living see: http://knowledgeforliving.org/index.php?id=about

${ }^{32}$ See Fleet Farming blog titled, "Head Start at Knowledge For Living": https://fleetfarming.org/head-start-knowledge-living/
} 
Future research in this area should examine the long-term effects of this and other environmental sustainability and social justice focused programs in terms of the organization's initial goals, actual practices, and resulting effects in marginalized communities. Furthermore, scholars could replicate this research in many communities around the US and elsewhere, to examine local food security and sustainability initiatives. The results of such work, when scholars share their data, would benefit the organizations as well as governmental structures about how to improve programs, address social justice issues, and move toward more inclusive grassroots interventions. Yet, volunteers and employees of non-profit organizations may not read critical scholarly analyses of non-profits, thus leaving a potential gap in understanding of how said groups can utilize evidence-based knowledge. Therefore, my commitment to sharing my results with Fleet Farming not only helps to fill this gap in how ideas are disseminated, but also facilitates the direct use of my scholarship. Continued research with Fleet Farming should expand the understanding of actors' perspectives by focusing on the Parramore community, their needs and struggles, current sustainability/subsistence practices, and how Fleet Farming or other groups can address the social, political, and environmental issues related to food insecurity with the Parramore community. In the long term, Fleet Farming is keeping detailed metrics and data to analyze their impact holistically, and to form mutually beneficial relationships with community members and leaders. This is a promising approach and one that could provide a model for other similar organizations.

The global food insecurity crisis is a result of the interplay of environmental, economic, social, political, and cultural factors (Himmelgreen and Romero-Daza 2009). Therefore, future social science research on sustainability and food/environmental justice should shift from 
focusing solely on the benefits of such programs, to analyzing sustainability programs with a critical eye. To achieve this, research on sustainability would benefit from utilizing James Greenberg and Thomas Park’s (1994) political ecology framework, which analyzes the relationships between the environment, politics, and society as a cohesive dynamic. This theoretical framework requires researchers to directly define sustainability, who it affects, and how, thus politicizing sustainability. Working under this framework, researchers could situate their analyses in a way that explores how power relations are reflected through sustainability projects (McLaren 2003). Ultimately, the understandings gained from more politicized public discussions of sustainability may open doors for organizations and communities to truly achieve their sustainability goals and improve people's quality of life. 


\section{REFLECTIONS}

My involvement in food and environmental justice activities in Orlando gave me an insider position, providing me familiarity with the topic and participants. My background allowed me to focus on asking critical questions, as I had already been mystified and demystified by sustainability and could better understand it for what it is rather than for what people tout it to be. One significant struggle, however, was that I am, unmistakably, a woman of color, which made it difficult to have discussions about race with other Fleet Farmers. I believe that my skin color and the nature of the questions I was asking inhibited me from delving into how race plays such a significant role in their program in Parramore. Yet, this challenge became evidence to support my claims about the non-political engagement in environmental justice issues. Now that there are some other interns of color in Fleet Farming, this has changed, and race is a more comfortable topic, particularly at the Parramore branch.

My positionality as a woman of color and coming from a low-income background influenced my analysis in several ways. It first led me to the topic and ultimate focus of my study, which seeks to understand how American race and class dynamics influence the availability of food in different areas and peoples' strategies to access food. I approached this topic with a personal understanding of how race and class operate within environmentalism. I am sympathetic to low-income single parents who must manage several jobs and children, and lack the time to grocery shop and/or prepare meals. I empathize with teens who struggle with obesity because they cannot afford fresh foods and children who must take the responsibility of acquiring food for their family. I also understand how uncomfortable it can be to be the only 
person of color at a farmer's market, environmentalist meeting, gardening event, meatless potluck, etc. My position made me aware of an issue that is common to countless urban areas in the U.S., yet it remains understudied - perhaps due to the lack of racially diverse scholars in anthropology who might offer unexplored perspectives like my own. While one could argue that my background and identity might serve as impediments to my objectivity, I believe my positionality makes me better equipped to critically explore this topic. 
APPENDIX A: IRB APPROVAL 


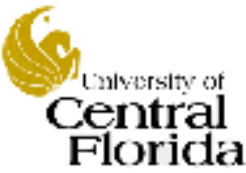

University of Central Florida Institutional Review Board Office of Research \& Commercialization

12201 Research Parkway, Suite 501

Orlando, Florida 32826-3246

Telephone: $407-823-2901$ or 407-882-2276

www research ucf.edu/compliance/irb html

\section{Approval of Exempt Human Research}

From: UCF Institutional Review Board \#1

FWA00000351, IRB00001138

To: Joanna Zofia Mishtal and Sarah G Davenport

Date: April 10, 2017

Dear Researcher:

On 04/10/2017, the IRB approved the following activity as human participant research that is exempt from regulation:

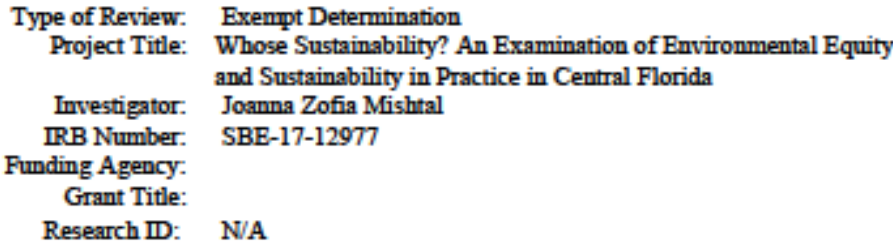

This determination applies only to the activities described in the IRB submission and does not apply should any changes be made. If changes are made and there are questions about whether these changes affect the exempt status of the human research, please contact the IRB. When you have completed your research please submit a Studv Closıre request in iRIS so that IRB records will be accurate.

In the conduct of this research, you are responsible to follow the requirements of the Investigator Mannal

On behalf of Sophia Dziegielewski, Ph.D, L.C.S.W., UCF IRB Chair, this letter is signed by.

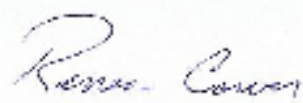

Signature applied by Renea C Carver

IRB Coordinator on 04/10/2017 01:39:18 PM EDT

Page 1 of 1 


\section{APPENDIX B: EXPLANATION OF RESEARCH}




\section{University of \\ Central Florida}

\section{EXPLANATION OF RESEARCH}

Title of Project: Whose Sustainability? An Examination of Environmental Equity and

Sustainability in Practice in Central Florida.

Principal Investigator: Sarah Davenport, HIM Candidate

Faculty Supervisor: Joanna Mishtal, PhD.

You are being invited to take part in a research study. Whether or not you take part is up to you.

The purpose of this research is to understand Fleet Farming's sustainability agenda and practices and its relationships to environmental equity.

What you should know about a research study:

Someone will explain this research study to you.

A research study is something you volunteer for.

Whether or not you take part is up to you.

You should take part in this study only because you want to.

You can choose not to take part in the research study.

You can agree to take part now and later change your mind.

Whatever you decide it will not be held against you.

Feel free to ask all the questions you want before you decide.

What you will be asked to do in the study: You will be asked to participate in an interview. The 
interview should take between 30-60 minutes at a place convenient for both the investigator and the participant.

Location: The interviews will take place at East End Market or at the Farmlettes a private space or in an agreed upon place that offers privacy.

Time required: Approximately 30-60 minutes will be required. The participants will be asked to participate in an interview at a time that is convenient for the participant.

This study is confidential. A pseudonym will be assigned to you in order to ensure confidentiality, unless you request that your name be used in this study.

Study contact for questions about the study or to report a problem: If you have questions or concerns about your participation in this research please contact: Sarah Davenport, HIM Candidate, Anthropology Program, College of Sciences, (239) 692-0144, Dr. Joanna Mishtal, Faculty Supervisor, Department of Anthropology at $+001(407) 823-3797$ or by email at jmishtal@ucf.edu.

IRB contact about your rights in the study or to report a complaint: Research at the University of Central Florida involving human participants is carried out under the oversight of the Institutional Review Board (UCF IRB). This research has been reviewed and approved by the IRB. For information about the rights of people who take part in research, please contact: Institutional Review Board, University of Central Florida, Office of Research \& Commercialization, 12201 Research Parkway, Suite 501, Orlando, FL 32826-3246 or by telephone at $+001(407)$ 823-2901. 
APPENDIX C: INTERVIEW GUIDE 
Project Title: "Whose Sustainability? An Examination of Environmental Equity and Sustainability in Practice in Central Florida"

(After Informed Consent)

Thank you for agreeing to talk with me today. I'm Sarah Davenport, and I'm an anthropologist based at the University of Central Florida. In this interview I'm interested in your experiences in the environmental sustainability movement and Fleet Farming specifically. All the information you give me will be confidential - I will not ask you for your name or any information that could identify you. You will not be compensated for your time. The interview is voluntary and it will take 30-60 minutes. Can I audio record our interview or would you prefer I didn't? Would you like to start now?

Research Site:

Date: Time:

Demographics:

I will begin with a few brief demographic questions:

a.) Age (please state):

b.) Education (please state the level):

c.) Neighborhood (please state the area you commute to events from)

d.) Employment (please state if full or part time, and type of work):

e.) Ethnicity (please state, as self-identified):

Questions about Experiences and Perspectives: 
Now I would like to ask you a few questions about your experiences.

1.) How did you become involved in the environmental sustainability movement/ Fleet Farming?(RQ1) [Probes: How and why? Did someone introduce you? Did you come alone? What role do you play (i.e. volunteer, employee, etc.)?]

2.) What encouraged you to stay involved/discontinue involvement with Fleet Farming? (RQ1) [Probes: Connections made with others? Sense of inclusion? Feeling like ideas are heard and considered? Were you able (time-wise, physically, financially) to continue involvement?] 3.) Who is involved in the creation of Fleet Farming initiatives?(RQ2) [Probes: Who decides what is planted and where? Who creates the ideas for gardens and fruit gleening? Who decides where to buy plants from and how much a farmlette will cost?]

4.) As a partner of IDEAS, Fleet Farming seems to support sustainability initiatives that are also connected to environmental justice issues, would you agree? (if yes) What does environmental Justice mean to you? (RQ1 \& 2)

5.) Do you feel that Fleet Farming incorporates environmental justice into their mission and practices? How/ why do you think that Fleet Farming doesn't/ incorporates this into their agenda and practices?(RQ 2) [Probe: Specific examples?]

6.) Do you feel that Fleet Farming makes their services accessible to low-income communities? (RQ 3) [Probes: Accessible financially and physically]

7.) As a self-identified member of ethnicity, do you feel as though your perspective/ideas are considered by the organization? (RQ 3) [Probes: do they allow you to suggest improvements/new ideas? Do they consider diverse perspectives?] 
8.) Do you feel that Fleet Farming tries to reach a diversity of communities? (RQ3)

[Probes: diversity of ethnicities/races and socioeconomic classes]

9.) What do you say is the ultimate goal/mission of Fleet Farming/ your participation in Fleet Farming in terms of how people think of/practice sustainability? (RQ2 \& 3)

10.) If you could choose only one neighborhood/community in Orlando for Fleet Farming to work in, what neighborhood would you choose and why? [Probes: Did you choose this because it would be most beneficial? Would they participate more than other communities?]

Thank you very much for your time. Please don't hesitate to contact me if there's anything else that you would like to add that you have not had a chance to say during this interview. Here's my and my advisor's contact information: Sarah Davenport, phone: 239-692-0144 (call/text), email: davenportsarah44@knights.ucf.edu Project Advisor: Joanna Mishtal, email: jmishtal@ucf.edu 
APPENDIX D: RECRUITMENT FLYER 


\section{Volunteers Needed for Fleet Farming Research Study}

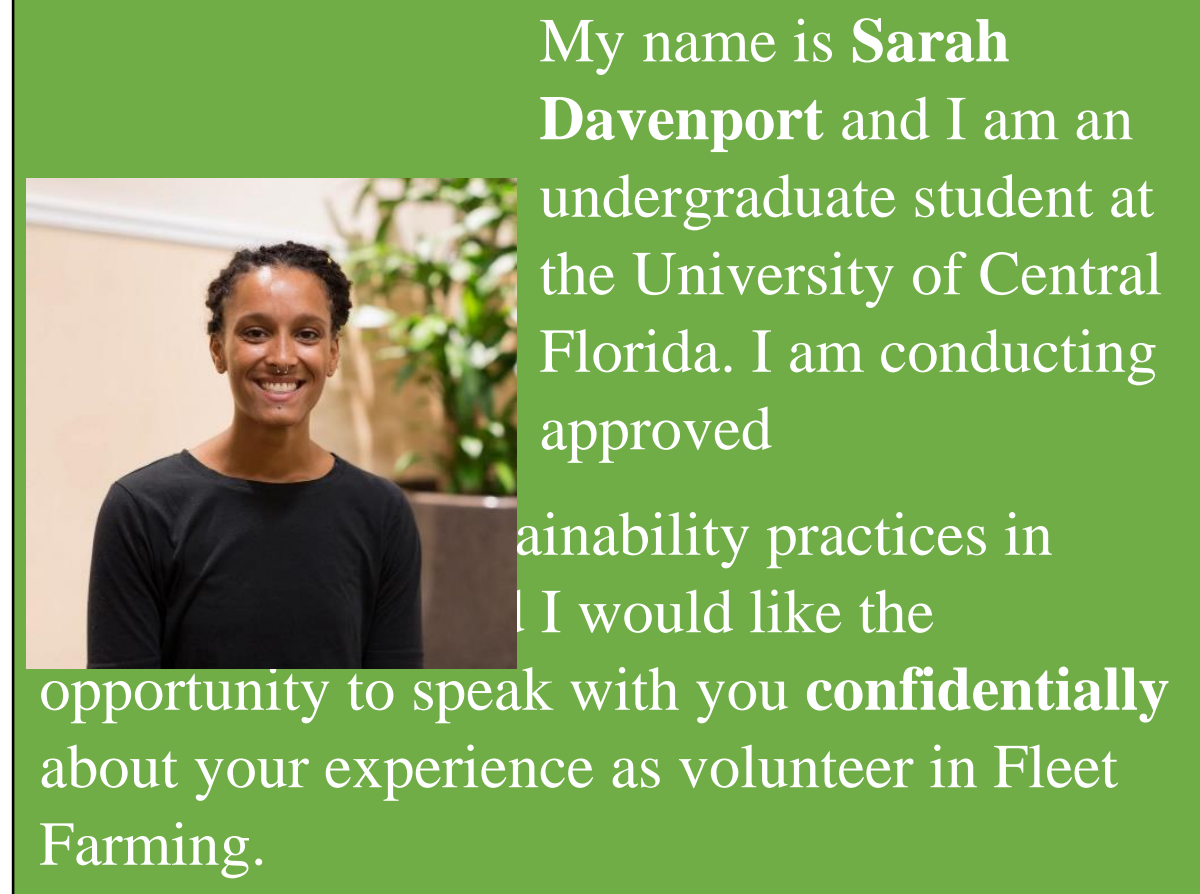

Research is confidential and approved by the University of Central Florida. 


\section{LIST OF REFERENCES}

Allen, P. 2008 "Mining for justice in the food system: perceptions, practices, and possibilities." Agriculture and Human Values 25(2):157.

Bernard, H. Russell. 2002 Research Methods in Anthropology. Walnut Creek: AltaMira Press.

Besteman, Catherine. 2013 "Three reflections on public anthropology." Anthropology Today 29 (6): $3-6$

Bullard, Robert D. 1994 Unequal Protection: Environmental Justice and Communities of Color. San Francisco: Sierra Club Books.

Checker, Melissa. 2011 "Wiped Out by the 'Greenwave': Environmental Gentrification and the Paradoxical Politics of Urban Sustainability.” City and Society 23 (2): 210-229.

Cherney, Elyssa. "Parramore leader sues Orlando over health problems at low-income housing project." Orlando Sentinel, July 2, 2015. http://www.orlandosentinel.com/news/local/osorlando-housing-project-health-lawsuit-20150702-story.html

Clendenning, Jessica; Dressler, Wolfram H.; Richards, Carol. 2016 "Food Justice or Food Sovereignty? Understanding the Rise of Urban Food Movements in the USA." Agriculture and Human Values 33 (1) 165-177.

DeWalt, Kathleen \& DeWalt, Billie R. 2011 Participant Observation a Guide for Fieldworkers. Second Edition. Walnut Creek: AltaMira Press.

Escobar, Arturo. 1997 “Anthropology and development.” International Social Science Journal 49 (154): 497-515. 
Faber, Daniel R. and McCarthy, Deborah. 2003. "Neo-Liberalism, Globalization and the Struggle for Ecological Democracy: Linking Sustainability and Environmental Justice.” In Just Sustainabilities: Development in an Unequal World, Edited by Julian Agyeman, Robert D. Bullard, and Bob Evans, 38-63. Cambridge: The MIT Press.

Farmer, Paul. 2004 “An Anthropology of Structural Violence,” Current Anthropology 45 (3): 305-325.

Farmer, Paul. 2005 Pathologies of Power: Health, Human Rights, and the New War on the Poor. Berkeley and Los Angeles: University of California Press.

Fetterman, David M. 2010 Ethnography: Step By Step. Newbury Park: Sage Publications. Gezon, Lisa. 2012 "Drug Crops and Food Security: The Effects of Khat on Lives and Livelihoods in Northern Madagascar." Culture, Agriculture, Food and Environment 34 (2): 124-135.

Gottlieb, Robert. 1993 Forcing the Spring: The Transformation of the American Environmental Movement. Washington, D.C.: Island Press.

Greenberg, James B. and Park, Thomas K. 1994 Political Ecology. Tuscon: University of Arizona,

Gunder, Michael. 2006 “Sustainability: Planning’s Saving Grace or Road to Perdition?” Journal of Planning Education and Research 26 (2): 208-221.

Guthman, Julie. 2008 “"If They Only Knew’: Color Blindness and Universalism in California Alternative Food Institutions." The Professional Geographer, 60 (3): 387-397.

Hanafi, Elyes. 2016 "The Spa-cial Formation Theory: Transcending the Race-Class Binary in Environmental Justice Literature” Antipode 49 (2): 397- 415. 
Himmelgreen, David and Romero-Daza, Nancy. 2009 "Anthropological Approaches to the Global Food Crisis: Understanding and Addressing the 'Silent Tsunami."' Napa Bulletin 32: 1-11.

Holifield, Ryan. 2001 "Defining Environmental Justice and Environmental Racism”. Urban Geography 22 (1): 78-90.

Kelly, Jason. "Fourth Generation Orlando Resident explains gentrification in Orlando.” Orlando Sentinel, March 19, 2015 http://www.orlandosentinel.com/opinion/os-ed-parramoregentrification-newvoices-031915-20150318-story.html

Lambert-Pennington, Katherine \& Hicks, Kathryn. 2016 “Class Conscious, Color-Blind: Examining the Dynamics of Food Access and the Justice Potential of Farmers Markets." Culture, Agriculture, Food and Environment 38 (1): 57-66.

Larsen, Kristian \& Gilliland, Jason. 2009 “A farmers” market in a food desert: Evaluating impacts on the price and availability of healthy food." Health \& Place 15 (4) 1158-1162.

Lavelle, Marianne and Coyle, Marcia. 1992 "Unequal Protection: The Racial Divide in Environmental Law, a Special Investigation.” The National Law Journal 15 (3).

Matos, Allison. 2016 Teach Them to Eat: Complexities of Community Based Organization and Nutrition Education Initiatives in the Prevention of Chronic Disease. Master's dissertation. Retrieved from https://pdfs.semanticscholar.org/f269/3aee2a661682de9ecf01a8f846804b224b14.pdf McLaren, Duncan. 2003 “Environmental Space, Equity, and the Ecological Debt.” In Just Sustainabilities: Development in an Unequal World, Edited by Julian Agyeman, Robert D. Bullard, and Bob Evans, 38-63. Cambridge: The MIT Press 
Mello, Christina; King, Lisa Oliver; Adams, Inez. 2017 “Growing Food, Growing Consciousness: Gardening and Social Justice in Grand Rapids, Michigan." Culture Agriculture Food and Environment Early View doi:10.1111/cuag.12091

Naess, Arne. 1989 Ecology, Community and Lifestyle: Outline of an Ecosophy. Rothenberg. Cambridge: Cambridge University Press.

Orlando City Hall 2016. "City of Orlando Receives Grant from USDA to Expand Local Food Access in West Orlando.” Accessed January 9, 2018. http://www.cityoforlando.net/news/2016/10/city-of-orlando-receives-grant-from-usda-toexpand-local-food-access-in-west-orlando/.

Passidomo, Catarina 2014 "Whose right to (farm) the city? Race and food justice activism in post-Katrina New Orleans.” Agriculture and Human Values 31 (3): 385-396.

Porter, Tana Mosier. 2004 “'Segregation and Desegregation in Parramore: Orlando’s African American Community.” The Florida Historical Quarterly 82(3): 292.

Poulsen, Melissa N.; Hulland, Kristyna R. S.; Gulas, Carolyn A.; Pham, Hieu; Dalglish, Sarah L.; Wilkinson, Rebecca K.; Winch, Peter J. 2014 “Growing an Urban Oasis: A Qualitative Study of the Perceived Benefits of Community Gardening in Baltimore, Maryland." Culture Agriculture Food and Environment 36 (2): 69-82.

Ramírez, Margaret Marietta. 2014 “The Elusive Inclusive: Black Food Geographies and Racialized Food Spaces.” Antipode 47 (3): 748-79.

Reynolds, Kristen. 2015 “Disparity Despite Diversity: Social Injustice in New York City's Urban Agriculture System.” Antipode 47 (1): 240-259. 
Rylko-Bauer, Barbara; Singer, Merrill; van Willigen, John. 2006 "Reclaiming Applied Anthropology: Its Past, Present, and Future" American Anthropologist 108 (1): 178-190

Shiva, Vandana. 2016 “Seed Sovereignty, Food Security” In Seed Sovereignty, Food Security: Women in the Vanguard, edited by Vandana Shiva. Berkeley: North Atlantic Books.

Schuller, Mark. 2012 Killing with kindness: Haiti, international aid, and NGOs. New Brunswick: Rutgers University Press

U.S. Census Bureau; American Community Survey, 2011-2015, Detailed Tables; generated by Sarah Davenport October 5, 2017; using American FactFinder. 